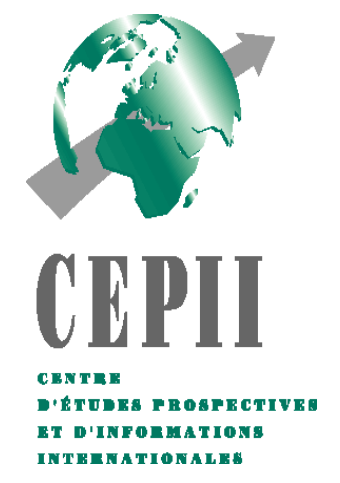

No 2005 - 06

May

Migration, Trade and Wages

Alexander Hijzen and Peter Wright 
Migration, Trade and Wages

Alexander Hijzen and Peter Wright

No 2005 - 06 May 


\section{TABLE OF CONTENTS}

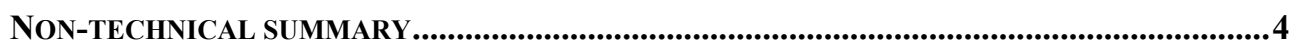

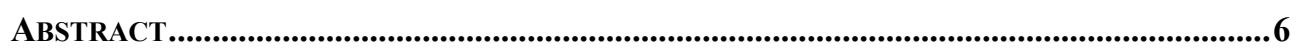

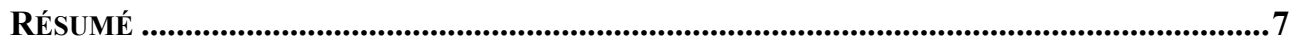

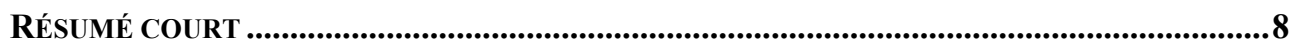

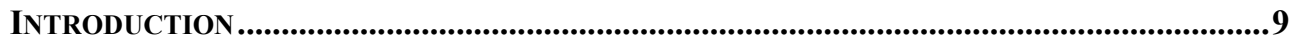

2. Migration Into The United Kingdom .................................................................11

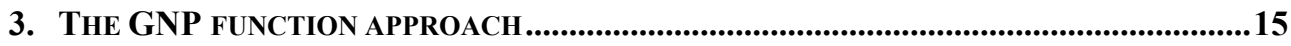

The Basic Model......................................................................................... 15

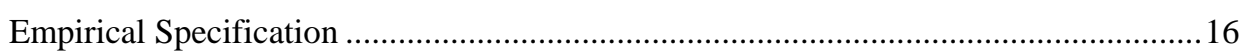

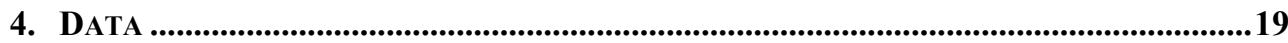

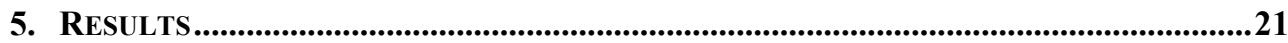

Trade, Wages and Exogenous Migration...............................................................21

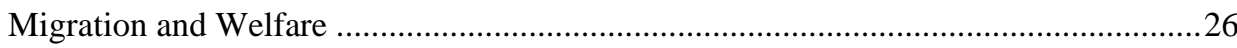

Trade, Wages and Endogenous Migration................................................................27

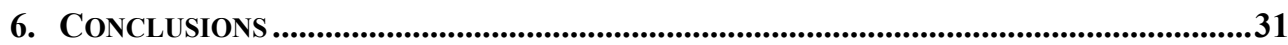

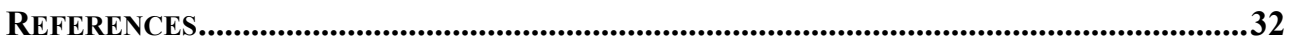

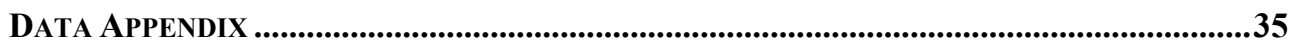

LIST OF WORKING PAPERS RELEASED BY CEPII .........................................................37 
Migration, Trade and Wages

\section{Migration, Trade AND WAges}

\section{NON-TECHNICAL SUMMARY}

Few issues are more politically sensitive than that of immigration. The promise of 'controlled immigration' was central to the manifesto promises of the Conservative Party at the 2005 General Election. This they sought to do by introducing a points-based system for work permits that gave 'priority to people with the skills Britain needs'. In addition the Conservatives sought to stem the flow of 'bogus' asylum seekers and stated that they would 'take back powers from Brussels to ensure national control of asylum policy, withdraw from the 1951 Geneva Convention, and work for modernised international agreements on migration'. Further, there would be an absolute cap to the total number of immigrants allowed to enter the UK, including a fixed quota on the number of asylum seekers.

The other political parties were also not immune from the pressure to tighten up administrative procedures relating to immigration. Both the Labour Party and the Liberal Democrats committed themselves to introducing a points based system, which would effectively exclude the lowest skilled from entering the UK to work. The tightening up on asylum procedures would also seek to stop economic migrants entering via this route.

So why should these concerns exist? Opponents of immigration will often point to the supposedly adverse impact of migrant flows on labour market outcomes. The argument runs that relaxing immigration controls will allow a flood of (presumably) low skilled 'economic migrants' who will displace some UK nationals from jobs and reduce the wages of others.

Much the same arguments have been made against trade liberalisation. The fear that trade with low wage economies will have adverse consequences for the wage and employment conditions of low skilled workers is one that is deeply held in the popular consciousness. It is also a hypothesis that has received much attention in the empirical economics literature.

To proponents of globalisation, the defence made for relaxed controls on the international movement of labour are similar to those made for reductions in barriers to trade. Free movement of labour and free trade enhance the allocation of resources and should thereby contribute to aggregate welfare. However, like trade, immigration is likely to have distributional consequences, which will lead to both winners and losers.

Despite the distinct parallels in the issues involved (and in the techniques adopted), an issue that has been largely ignored by both literatures is that trade and immigration are not independent features of globalisation. Moreover, apart from providing a comprehensive perspective on the debate on globalisation and labour markets, the question as to how and to what extent immigration and trade are related is potentially important in its own right. To the extent that migration reduces trade barriers of different types it may contribute to a superior allocation of resources thereby improving aggregate welfare. 
In this paper we simultaneously analyse the impact of trade and migration on the UK economy using data for the period 1975-1996. More in particularly, we evaluate in a single framework that is derived directly from production theory, to what extent migration affects the distribution of income through its impact on the UK labour market and how migration and UK trade are interrelated. We thereby distinguish between skilled and unskilled migrants, skilled and unskilled residents, as well as native and non-native resident workers.

We arrive at very similar conclusions whether we assume that migration is entirely determined by administrative controls or that it is solely driven by market forces, i.e. responding to factor rewards. In the former case, a relaxation of controls, which allows an increase in the number of unskilled migrants, reduces the wages of unskilled domestic workers. While the quantitative impact on foreign born unskilled workers may be sizeable it is very small for native unskilled workers. By contrast, relaxing controls on the entry of skilled workers appears to have no discernible impact on their domestic counterparts, with the wages of both skilled native and foreign-born workers remaining unaffected. When the number of migrants is treated as endogenous to the model, the impact of migration is measured by changes in the migrant wage. As before this indicates that unskilled migrants and unskilled domestic workers are substitutes.

The results further suggest that an increase in unskilled migrants reduces imports whilst an increase in skilled overseas workers sucks in more imports. This suggests that unskilled migrant workers and imports are substitutes in production, whilst skilled migrant workers and imports are complements. This presumably reflects the low skilled labour that is embodied in imports.

When we look at the overall impact of migration on the welfare of domestic factors we find that the contribution of unskilled immigration to national income is greater than that of skilled immigration. This suggests that unskilled migrants play a more complementary role to domestic factors than do skilled migrants. However, in economic terms the impact of migration on aggregate welfare is quite small, which is perhaps not surprising given the relatively small redistributive effects.

In short, we conclude from the results that the current political furore over migration cannot be justified by looking for labour market consequences of migration, since these impacts prove to be modest. 


\begin{abstract}
This study adopts a GNP function approach in order to examine the impact of migrant labour on domestic factors of production in the United Kingdom during the period 19751996. We also examine the relationship between imports and migrants, which are two different facets of globalisation. We find that an increase in the number of unskilled migrants reduces the wages of unskilled domestic workers. However the quantitative impact of this increase is small. No discernible impact of migration is found for skilled native workers. The results also suggest that unskilled migrant workers and imports are substitutes in production, whilst skilled migrant workers and imports are complements.
\end{abstract}

JEL Classification: C31, D33, F11, F16, F22

Keywords: $\quad$ Immigration, International Trade, Wage Inequality 


\section{MIGRATION, COMMERCE EXTÉRIEUR ET SALAIRES}

\section{RÉSUMÉ}

Peu de sujets sont politiquement plus sensibles que celui de l'immigration. Le débat concerne surtout les effets de l'immigration sur le marché de travail. Les opposants à l'immigration mettent en avant les conséquences présumées négatives de l'immigration sur le marché de travail, en arguant qu'une suppression des contrôles sur l'immigration induirait un afflux d'immigrés peu qualifiés dont la motivation est principalement économique, qui prendraient l'emploi de certains travailleurs nationaux et abaisseraient le salaire d'autres. Des arguments similaires ont été développés à propos du commerce international. La crainte que l'ouverture aux échanges avec des pays de salaires bas n'ait des conséquences adverses pour les conditions de salaires et d'emploi des non-qualifiés est très répandue, et cette question a également été le sujet des nombreuses études économiques appliquées.

Quant aux défenseurs de la mondialisation, les arguments avancés pour assouplir le contrôle du mouvement international des travailleurs sont similaires à ceux invoqués pour le libre-échange. La libre circulation de travailleurs ainsi que le libre-échange améliorent l'allocation des ressources et contribuent ainsi au bien-être d'ensemble. Néanmoins, il est probable que l'immigration ait, comme le libre-échange, des conséquences significatives pour la distribution des revenus, avec des gagnants mais aussi des perdants.

En dépit de ces parallèles, la possible interdépendance entre le commerce international et l'immigration a été peu étudiée. Or, outre la perspective d'ensemble qu'elle peut offrir sur les conséquences de la mondialisation, l'interaction entre le commerce et la migration est un sujet d'intérêt à part entière. Dans la mesure où l'immigration est susceptible de réduire différents types d'obstacles aux échanges, elle pourrait contribuer à une meilleure allocation des ressources, source de gains de revenu réel.

Dans cette étude, nous analysons simultanément l'impact du commerce extérieur et de l'immigration sur l'économie britannique en utilisant des données statistiques pour la période 1975-1996. Nous évaluons en particulier, dans un cadre unique fondé sur la théorie de production, dans quelle mesure l'immigration affecte la distribution de revenu à travers ses effets sur le marché de travail, et comment l'immigration et le commerce extérieur sont liés. Pour ce faire, deux niveaux de qualifications sont considérés parmi les immigrés comme parmi les travailleurs nationaux.

Que l'immigration soit supposée complètement déterminée par la réglementation ou qu'elle soit considérée comme résultant du jeu des forces du marché, c'est-à-dire répondant aux variations des salaires potentiels, les résultats des estimations sont très semblables. Dans le premier cas, nos résultats suggèrent qu'une politique d'immigration plus libérale permettant une augmentation du nombre d'immigrés non qualifiés réduit les salaires des travailleurs locaux non qualifiés. L’impact est néanmoins très faible. En revanche, une augmentation du nombre d’immigrés qualifiés n'a pas d'effet discernable sur les salaires des locaux. 
Quand le nombre d'immigrés est supposé endogène, l'impact de l'immigration est évalué à travers les changements dans le niveau de salaire potentiel des immigrés. Comme précédemment, les résultats suggèrent que la main-d'œuvre immigrée non qualifiée est un substitut à la main-d'œuvre locale non qualifiée.

Enfin, les résultats indiquent dans les deux cas que l'augmentation d'immigrés non qualifiés réduit les importations britanniques, tandis qu'une augmentation du nombre d'immigrés qualifiés accroît les importations. L'immigration des non qualifiés agirait donc dans le processus de production comme un substitut aux importations, tandis que l'immigration qualifiée serait au contraire complémentaire des importations. Ces résultats reflètent probablement la forte intensité en travail non qualifiée des importations britanniques.

\section{RÉSUMÉ COURT}

Cette étude examine l'impact de la migration sur le marché du travail au Royaume-Uni en adoptant une approche de fonction PNB. Nous étudions aussi la relation entre importations et immigration, deux aspects différents de la mondialisation. Nous trouvons qu'une augmentation du nombre d'immigrés non qualifiés réduit le salaire des travailleurs locaux non qualifiés. L'impact est néanmoins très faible. En revanche, une augmentation du nombre d'immigrés qualifiés n'a pas d'effet discernable sur les salaires des locaux. Les résultats suggèrent également que la main-d'œuvre immigrée non qualifiée est un substitut aux importations, tandis que le travail immigré qualifié apparaît complémentaire aux importations.

Classification JEL : C31, D33, F11, F16, F22

Mots-clés: $\quad$ Immigration, commerce international, inégalités salariales 


\title{
Migration, Trade AND Wages
}

\author{
Alexander Hijzen ${ }^{1}$ and Peter Wright
}

\section{INTRODUCTION}

Few issues are more politically sensitive than that of immigration. The promise of 'controlled immigration' was central to the manifesto promises of the Conservative Party at the 2005 General Election. This they sought to do by introducing a points-based system for work permits that gave 'priority to people with the skills Britain needs'. In addition the Conservatives sought to stem the flow of 'bogus' asylum seekers and stated that they would 'take back powers from Brussels to ensure national control of asylum policy, withdraw from the 1951 Geneva Convention, and work for modernised international agreements on migration'. Further, there would be an absolute cap to the total number of immigrants allowed to enter the UK, including a fixed quota on the number of asylum seekers.

The other political parties were also not immune from the pressure ${ }^{2}$ to tighten up administrative procedures relating to immigration. Both the Labour Party and the Liberal Democrats committed themselves to introducing a points based system, which would effectively exclude the lowest skilled from entering the UK to work. The tightening up on asylum procedures would also seek to stop economic migrants entering via this route.

So why should these concerns exist? Opponents of immigration will often point to the supposedly adverse impact of migrant flows on labour market outcomes. The argument runs that relaxing immigration controls will allow a flood of (presumably) low skilled 'economic migrants' who will displace some UK nationals from jobs and reduce the wages of others.

Much the same arguments have been made against trade liberalisation. The fear that trade with low wage economies will have adverse consequences for the wage and employment conditions of low skilled workers is one that is deeply held in the popular consciousness. It is also a hypothesis that has received much attention in the empirical economics literature (Gaston and Nelson, 2002).

To proponents of globalisation, the defence made for relaxed controls on the international movement of labour are similar to those made for reductions in barriers to trade. Free

\footnotetext{
1 Address for correspondence: School of Economics, University of Nottingham, Nottingham, NG7 2RD. Tel + 44 (0)115 8466447. Fax: + 44 (0)115 9514159. E-mail: Alexander.Hijzen@nottingham.ac.uk Acknowledgements: We would like to thank Sébastien Jean for helpful comments and suggestions. All remaining errors are our own. Financial support through the Leverhulme Trust (Grant No. F114/BF) is gratefully acknowledged. Alexander Hijzen also thanks CEPII for their hospitality and acknowledges financial support from the ESRC under PTA-026-27-0733.

2 A MORI poll published in the Observer on the 10th April found that 69\% of the population would support either tougher controls on immigration or a complete halt to it.
} 
movement of labour and free trade enhance the allocation of resources and should thereby contribute to aggregate welfare. However, like trade, immigration is likely to have distributional consequences, which will lead to both winners and losers.

Given the similarity of the issues involved, strong parallels exist in the empirical strategies used to examine these questions. Gaston and Nelson (2002) divide the studies examining the impact of migration on domestic labour market outcomes into 'trade' and 'labour' economics approaches. This terminology parallels that from Slaughter's (1999) earlier survey examining the impact of increased trade. The main distinction between these two approaches is in terms of their dimensionality. The trade approach is typically explicitly rooted in a multi-sector general equilibrium framework, of the type that underpins the Hecksher-Ohlin model. The labour approach, by contrast, is implicitly framed in partial equilibrium terms, and tends to place emphasis on modelling the institutional settings of the labour market. This approach stresses that unemployment and market imperfections are of primary importance, since they serve to moderate the impact of external shocks on the wage and employment structures. Much of this institutional detail is absent from 'trade' studies.

Despite the contrast in approaches, a certain degree of consensus has emerged from both literatures- that the impact of both trade and migration on labour markets is, at best, modest. Thus the measured impact of trade on the skilled-unskilled wage differential, whilst statistically significant, is small compared to that associated with skill-biased technological change (Turrini, 2002). Likewise, Gaston and Nelson (2002) state that 'the overwhelming majority of empirical studies conclude that there is essentially no statistically significant effect of immigration on labour market outcomes, with the possible exception of the least skilled domestic workers ${ }^{3}$.

Despite the distinct parallels in the issues involved, and in the techniques adopted, an issue that has been largely ignored by both literatures is that trade and immigration are not independent features of globalisation. Moreover, apart from providing a comprehensive perspective on the debate on globalisation and labour markets, the question as to how and to what degree immigration and trade are related is potentially important in its own right. To the extent that migration reduces trade barriers of different types it may contribute to a superior allocation of resources thereby improving aggregate welfare.

While early theoretical work on the relationship between trade and factor movements implied they were substitutes (Mundell, 1957), more recent contributions have suggested that complementarities may be important and even dominate substitution effects. A complementary relationship between migration and trade can result from: the potential taste bias of immigrants towards products from their home countries ('taste complementarities'); the country-specific knowledge of immigrants reducing potentially important informational barriers ('informational complementarities'); and shared cultural values which nourish trust and help to build long-term trading relationships ('ethnic or transaction

\footnotetext{
3 Exceptions to this conclusion are found in Borjas et al. (1992) and Huddle (1993). Borjas et al. (1992) conclude that immigration has had a proportionately greater negative impact on the wages of less skilled US workers than has increased trade exposure.
} 
complementarities'). A number of empirical studies have found evidence suggesting that the trade creating effects (imports and exports) of migration are indeed important (see Gould (1994) for the US, Head and Ries (1998) for Canada and Dunlevy and Hutchinson (1999) for a historical application to the US).

Only once the link between migration and trade is understood can a complete picture of the influence of trade and migration on the labour market be framed. An exception to this omission are Kohli's (1999, 2002) recent studies of the Swiss economy. In these papers he explicitly treats both migrants and imports as inputs into the production process and examines the relationship between them. He concludes that higher migration leads to higher levels of imports and lower levels of exports. Further, higher immigration lowers the income of domestic workers, or causes severe displacement effects if wages do not adjust downwards. Owners of capital on the other hand benefit.

In this paper we apply a similar approach to that of Kohli (1999) to the United Kingdom and adopt a production theory framework which enables us to directly examine the relationship between migrants and other inputs in the production process. This allows us to assess the impact of an increase in immigration on relative factor demand and relative factor prices. This fills a significant gap in the literature since relatively little research has been conducted on the labour market impact of migration for the United Kingdom. As outlined above, the framework adopted also allows us to examine the link between migration and trade. We extend the work by Kohli (1999) by also examining how migration affects the relative returns of skilled domestic labour relative to unskilled domestic labour. This allows us additional insight into the distributional implications of trade and migration.

Section 2 sets out the patterns of migration into the United Kingdom and relates them to changes in immigration policy over the period. Section 3 then discusses the production theory approach to examining the impact of migration with section 4 examining the data set used. Section 5 then presents the econometric results for the United Kingdom. Finally, Section 6 concludes.

\section{MIGRATION INTO THE UNITED KINGDOM}

The size of the immigrant population has grown substantially over the past 50 years (Table 1). By 2001, more than 1 in 12 UK residents (4.9 million people) had been born overseas. This is almost double the proportion in 1951 (4.22\%).

Over this period, immigration into the United Kingdom has been subject to a number of legislative changes which have aimed to regulate the flow of migrants. However, unlike many other countries, the UK has never operated a points system whereby only those judged to have desirable socioeconomic characteristics are allowed entry, and the UK has remained relatively open to immigration. Citizens of the Irish Republic have always been free from immigration control and, in the immediate post-war period, the United Kingdom also maintained a liberal regime for its (former) colonies. The 1948 British Nationality Act allowed a right of entry to citizens of those countries that remained within the commonwealth, which permitted immigration from the New Commonwealth during the 
1950s and $1960 \mathrm{~s}^{4}$. Political pressures however saw a progressive tightening of these rules, until the 1971 Immigration Act effectively placed Commonwealth citizens on an equal footing to other foreign nationals. Although immigration from the Commonwealth became more regulated, a countervailing force was the entry of the United Kingdom into the European Union in 1972, which meant that citizens of other EU member states were now free to work in the UK.

Table 1: Overseas-born population as a percentage of total UK population

\begin{tabular}{cc}
\hline \hline Year & Percentages \\
\hline 1951 & 4.22 \\
1961 & 4.88 \\
1971 & 5.75 \\
1981 & 6.23 \\
1991 & 6.69 \\
2001 & 8.33 \\
\hline \hline
\end{tabular}

Source: Censuses, April 1951 to 2001, Office for National Statistics; General Register Office for Scotland; Northern Ireland Statistics and Research Agency

Over this period, there has also been a significant flow of migrants who have been allowed to enter the UK on work permit schemes. The aim of this policy has been to meet domestic shortfalls in labour supply and, under the scheme, employers apply for permits on behalf of a foreign worker in order to fill a job for which they are unable to find a suitable applicant from the EEA states. ${ }^{5}$ Under this scheme, the number of work permits issued grew steadily from around 30,000 a year in 1951 to almost 70,000 a year in 1971. This rise was abated by the 1971 Immigration Act, which tightened the regulations governing the issuing of permits by placing Commonwealth citizens on the same footing as other non-EU applicants. As a consequence, the number of work permits fell to about 15,000 in the early 1980 s. Since then, the number of permits issued has risen sharply, with more than 129,000 being issued in 2002 (Clarke and Salt, 2003). The vast majority of these were in higher skilled categories (managerial, professional, associate professional and technical occupations).

It is worth noting at this juncture that those allowed entry on work permits are only granted temporary leave to stay. Work permits are granted for a particular job, and for a limited period of time. Permits may be extended if the individual wishes to work longer for the same employer. However, if the individual wishes to change employment then they must apply for a new permit. Indeed, Rendall and Ball (2004) point out that much migration to the UK, from whatever source, is of a temporary nature and they estimate that almost half of those entering the UK re-migrate within five years. Likewise, Glover et al. (2001) suggest that the balance of migration that was maintained throughout the 1980s and early 1990s levels was at least partly a result of the return flows of foreign nationals. From the

4 The ‘Old Commonwealth' consists of Australia, New Zealand, Canada and South Africa. The 'New Commonwealth' comprises the remaining countries.

5 There are no quotas on the number of work permits issued. 
mid 1990s, net migration to the UK has increased significantly as entrants have outnumbered those returning. Net immigration has risen from around zero in the early 1990 s to more than 150,000 a year in 2005 . Thus migration is a more dynamic phenomenon than simple consideration of stocks might suggest.

The migrant population represents an extremely diverse group in terms of ethnic mix. Prior to 1960 most immigration into the UK was from Ireland and Europe, with relatively low rates from elsewhere. The 1960s and 1970s saw a reversal of this pattern. Immigration from Europe fell, and the UK witnessed a growth in immigration from the Indian sub-continent, East Africa and the Caribbean. Following entry into the EU and a tightening of controls on immigration from former colonies, the 1980s saw an increase in migration from Ireland and Western Europe and a decline from India. During the late 1990s, net immigration to the UK has increased significantly and further broadened the ethnic background of the migrant population. (Glover et al., 2001). A particular feature of migration in the last decade has been the expansion of those claiming asylum. The number claiming asylum rose from 4000 in 1988 to 71,000 in 1999, peaking at around 100,000 in $2002^{6}$.

These changes in the characteristics of the migrant population clearly reflect themselves in the changing characteristics of the migrant workforce. Table 2 gives a breakdown of the migrant workforce according to the country of origin for the period covered in this study. Notable over this period is the decline in the relative importance of Irish immigrants and the increased prevalence of workers from non-European and non-Commonwealth countries.

Table 2: Composition of immigrant workforce by country of origin

\begin{tabular}{crrrrr}
\hline \hline Year & & & & \\
\hline Country of Origin & $1974-78$ & $1979-83$ & $1984-88$ & $1989-93$ & $1994-98$ \\
Ireland & 23.1 & 17.0 & 16.5 & 15.0 & 11.6 \\
Europe & 17.0 & 14.6 & 14.9 & 13.9 & 16.7 \\
Mediterranean Commonwealth & 4.3 & 4.5 & 4.7 & 4.2 & 4.1 \\
Old Commonwealth & 3.9 & 3.2 & 3.7 & 3.3 & 5.8 \\
India and Bangladesh & 15.6 & 21.1 & 15.4 & 16.4 & 16.4 \\
Pakistan & 6.7 & 6.3 & 6.0 & 7.9 & 5.7 \\
East Africa & 5.4 & 7.5 & 9.3 & 9.3 & 9.4 \\
Caribbean & 12.1 & 11.3 & 8.9 & 7.8 & 5.5 \\
Other Commonwealth & 6.3 & 7.1 & 8.5 & 9.9 & 10.2 \\
Rest of World & 5.6 & 7.3 & 12.1 & 12.4 & 14.6 \\
\hline \% of workforce foreign born & 6.8 & 7.5 & 8.0 & 7.8 & 7.8 \\
\hline \hline
\end{tabular}

Source: Author's calculations from General Household Survey.

\footnotetext{
${ }^{6}$ The main source countries for these entrants were Iraq, Sri Lanka, Somalia, Turkey, Former Yugoslavia and China.
} 
Can anything be said more generally regarding the characteristics of the migrant population? Firstly, the overseas-born population are young in comparison with the UKborn population. About three-quarters of the overseas-born population were of working age in 2001, compared to only about three-fifths of those native born.

Secondly, migrants are more diverse than the native population in terms of their educational qualifications, reflecting the diverse background and educational systems of migrants (Glover et al, 2001). The relatively liberal policies on migration and the fact that the UK has never operated a 'points' system, which in other OECD countries excludes people with 'undesirable' socio-economic characteristics, might suggest that the UK would attract workers with relatively poor levels of skill and education. In fact, immigrants to the UK actually have higher levels of education than the native population. Bell (1997) pools the GHS from 1973 to 1992 and shows that the average number of years of schooling for the native population is more than a year less than that for immigrants (Table 3), with immigrants from India having particularly high levels of education. Further, the average level of education of immigrants is increasing with each new arrival cohort.

Table 3: Average years of schooling by country of birth and cohort

\begin{tabular}{|c|c|c|c|c|c|c|}
\hline & Native & Immigrant & \multicolumn{4}{|c|}{ Immigrant Cohort } \\
\hline & & & Pre-1960 & $1960-9$ & $1970-9$ & $1980-9$ \\
\hline All & 10.94 & 12.04 & 11.28 & 12.07 & 13.36 & 13.70 \\
\hline Whites & & 11.23 & 10.85 & 11.36 & 12.77 & 13.28 \\
\hline Indian & & 12.68 & 12.28 & 12.56 & 13.33 & 13.76 \\
\hline West Indian & & 10.85 & 10.55 & 10.92 & 11.94 & 12.00 \\
\hline
\end{tabular}

Source: (Bell, 1997). Sample restricted to males aged over 18 who have completed full time education.

We would expect this increase in the education level of migrant cohorts to be reflected in the improving socio-economic position of migrants. Table 4 illustrates the increase in the proportion of the foreign workforce in skilled jobs over time ${ }^{7}$. The relatively poor social position of immigrants in earlier decades probably reflects the fact that the socio-economic group of migrants was lower than might be expected from their educational levels. That is, they tended to work in less skilled occupations than their levels of education would lead us to expect. Bell (1997) suggests that the wage disadvantage is particularly high for black immigrants, especially those with high levels of overseas work experience, for which they are not rewarded ${ }^{8}$. This may well still be the case, though note that foreign born workers now occupy more skilled jobs on average than domestic workers.

\footnotetext{
${ }^{7}$ Workers are separated into skilled and unskilled according to their socio-economic group. See data appendix for details.

${ }^{8}$ He does however find strong evidence for assimilation effects for this group.
} 
Table 4: Relative skill composition of native and foreign born workforces

\begin{tabular}{ccc}
\hline \hline Years & \% native skilled & \% foreign skilled \\
\hline $1974-1978$ & 63.6 & 56.4 \\
$1979-1983$ & 63.4 & 57.5 \\
$1984-1988$ & 63.0 & 58.6 \\
$1989-1993$ & 62.6 & 61.3 \\
$1994-1998$ & 63.5 & 64.1 \\
\hline \hline
\end{tabular}

Source: Author's calculations from General Household Survey. See Data Appendix for definition of skill.

\section{THE GNP FUNCTION APPROACH}

What then are the implications of the migration that has been documented for the domestic economy? The distributional implications of migration for the domestic factors will depend on whether the factors considered are complements or substitutes to foreign labour, since this will determine the impact on relative factor demand of an increase in immigration.

A natural framework within which to examine the relationship between inputs is that of production theory. In this section we begin by setting out this framework and then discuss how the impact of migration may be assessed. A number of specific issues relating to the UK context will be discussed. This will provide us with predictions regarding the impact of immigration on wages and imports and inform the econometric methodology that follows.

\section{The Basic Model}

In a closed economy context, the GNP function gives the maximum level of output $(y)$ for the economy for given output prices $(p)$, factor supplies $(v)$ and technology $(T)$ :

$$
G(p, v)=\max _{y}\{p \cdot y \mid(y, v) \in T\}
$$

The GNP function implies factor prices and output supplies, which are determined endogenously. It is assumed that this is twice differentiable in prices and factor endowments, increasing and convex in prices, increasing and concave in factor endowments.

In a simple closed economy model, the relevant factor supplies are capital $\left(v_{k}\right)$ and resident skilled $\left(v_{s}\right)$ and unskilled $\left(v_{u}\right)$ labour. One can extend the model to an open economy context by treating imports ${ }^{9}(m)$ as an additional input as suggested by (Burgess, 1974; Kohli, 1991). This is justified by noting that most trade is in raw materials and non-finished

\footnotetext{
9 Note that since imports are treated as intermediate inputs they are considered as negative outputs. The economy's GDP therefore equals the total value of its outputs minus the total value of imports. The advantage of modelling imports as negative outputs is that it allows one to stick to the production side of the economy.
} 
goods, and that a significant proportion of the price of imported final goods consists of domestic value added.

A straightforward extension is to treat migrant labour $\left(n_{s}, n_{u}\right)$ as an additional intermediate input into the production process. An important question in the context of migrant labour is whether it should be treated as endogenous, as in the case of imports, or exogenous to the model, as is the case with the domestic labour endowments. If the movement of migrant workers is determined by their expected returns of working in the United Kingdom, then the supply curve for migrant workers is upward sloping and the stocks of migrants should be considered as endogenous to the model. In this case, the output absorbed by migrant workers would be treated in a similar manner to imports- as a negative output. This model specification is reasonable when two conditions are met. First, when migration is free from significant regulatory impediments. Second, when the labour market itself is relatively rigid due to labour market institutions that prevent it from clearing rapidly in response to shocks (i.e. factor prices are exogenous).

By contrast, if it is felt that migration flows are largely determined by the regulatory environment, rather than by the decisions of migrants in response to earnings differentials, then migrant labour should be regarded as exogenously determined. As the UK labour market is considered to be relatively flexible and its immigration policy fairly liberal it is unclear which model specification is more adequate. Although migration controls are important for some groups of migrants, much immigration appears to be determined by economic considerations. In the present paper we therefore take an agnostic view as to which of these two assumptions is nearer to the truth. Thus, in the empirical part of the paper, we estimate two models: one that assumes migration stocks to be endogenous; one that assumes migration stocks to be exogenous.

\section{Empirical Specification}

In the empirical implementation employed in this paper, we assume a translog form for the GNP function:

$$
\begin{aligned}
& \ln G(p, v, t)=\alpha_{0}+\sum_{i=1}^{N} \alpha_{i} \ln p_{i}+\sum_{k=1}^{M} \beta_{k} \ln v_{k}+\frac{1}{2} \sum_{j=1}^{N} \sum_{i=1}^{N} \alpha_{i j} \ln p_{i} \ln p_{j} \\
& +\frac{1}{2} \sum_{k=1}^{M} \sum_{l=1}^{M} \beta_{k l} \ln v_{k} \ln v_{l}+\frac{1}{2} \sum_{i=1}^{N} \sum_{k=1}^{M} \gamma_{i k} \ln p_{i} \ln v_{k}+t \sum_{i=1}^{N} \delta_{i} \ln p_{i} \\
& +t \sum_{l=1}^{M} \delta_{k} \ln v_{k}+\delta_{1} t+\delta_{2}{ }^{2} t
\end{aligned}
$$

Where $p$ are the effective prices for industry $\{i, j\}, v$ is the utilisation of factor $\{k, l\}$ and non-neutral technological change is assumed to be a quadratic function of time $(t)$. The logarithmic effective price is defined as the sum of the log of value added prices and the log of total factor productivity (Hicks neutral technological change). This involves the implicit assumption that the impact of a proportional change in value-added prices on GNP is equal 
to that of a proportional change in total factor productivity (TFP), as is standard in trade theory.

A number of further restrictions are placed on the parameters of the model. The assumption of profit maximisation implies linear homogeneity in prices. Constant returns to scale are also assumed, which implies linear homogeneity in factor endowments. This gives rise to the following restrictions:

$$
\sum_{i=1}^{N} \alpha_{i}=\sum_{k=1}^{M} \beta_{k}=1 \quad \sum_{i=1}^{N} \alpha_{i k}=\sum_{k=1}^{M} \alpha_{i k}=\sum_{i=1}^{N} \beta_{i k}=\sum_{k=1}^{M} \beta_{i k}=\sum_{i=1}^{N} \delta_{i}=\sum_{k=1}^{M} \delta_{k}=0
$$

Without loss of generality, symmetry restrictions are also imposed by setting:

$$
\alpha_{i j}=\alpha_{j i} \quad \beta_{k l}=\beta_{l k} \quad \gamma_{i k}=\gamma_{k i}
$$

Estimation of this system is facilitated by noting that the factor share equations (or inverse factor demands) may be derived by differentiation of the revenue function (2) with respect to $\ln v_{k}$. Hence the share of factor $k$ in GNP, $s_{k}=\frac{w_{k} v_{k}}{Y}$, is given by:

$$
s_{k}=\beta_{0 k}+\sum_{j=2}^{N} \gamma_{k j} \ln \frac{p_{j}}{p_{1}}+\sum_{l=2}^{M} \beta_{k l} \ln \frac{v_{l}}{v_{1}}+\delta_{k} t
$$

Migrant shares are included as a factor $(k)$ when migration is treated as exogenous. Differentiation of the revenue function (2) with respect to effective prices $\left(\ln p_{i}\right)$ yields the share of final output $i$ in GNP:

$$
s_{i,-j}=\alpha_{0 i}+\sum_{j=2}^{N} \alpha_{i j} \ln \frac{p_{i}}{p_{1}}+\sum_{l=2}^{M} \gamma_{i l} \ln \frac{v_{k}}{v_{1}}+\delta_{i} t
$$

where $s_{i,-j}=\frac{p_{i} x_{i}}{Y}$ is the combined vector of final output shares in GNP and the negative vector of import shares in GNP. Migrant shares in GNP are also included when migrant flows are treated endogenously.

Note that the GNP function may straightforwardly be disaggregated to allow for more than one final output. Because of our interest in the impact of globalisation on skilled versus unskilled workers, we disaggregate total output into that arising from the skill and the unskill intensive sectors.

Although our prime interest is with the cost share equations, joint estimation with the output share equations leads to greater efficiency due to the correlation of the disturbances and due to the cross equation restrictions $\left(\gamma_{i k}=\gamma_{k i}\right)$. 
Note that since the cost share equations sum to one, the disturbance covariance matrix of the full system will be singular. Thus, one equation is dropped from the system for the purposes of estimation. The same is true for the output share equations. Note that invariance to which equation is deleted can be achieved by iterating the system estimator until the parameter estimates and the residual covariance matrix converge (Berndt and Wood, 1975).

We estimate the system using a version of Zellner's (1962) method for seemingly unrelated regression equations, which is equivalent to maximum likelihood. In addition, we use $\mathrm{GMM}^{11}$ in order to account for the potential endogeneity ${ }^{12}$ of domestic prices and first-order serial correlation. Note that the advantages of the GMM estimator over SUR reside in its large sample properties. In the present case with a small sample it is therefore unclear which estimator is to be preferred.

The results will be discussed on the basis of the estimated elasticities rather than the direct regression estimates whose interpretation is not straightforward due to the fact that the explanatory variables are in natural logarithms while the dependent variables are not. Instead of using the Hicksian elasticities of complementarity (the analogue of Allen-Uzawa elasticities of substitution in a cost function context) the direct price and quantity elasticities are reported. $^{13}$

${ }^{10}$ The $R^{2}$ measure for the goodness of fit reported by most statistical packages applies only to single equation regressions. In a system, the $R^{2}$ is no longer constrained between zero and one as system estimators do not share the same objective function (min. e'e). This paper therefore presents the generalised $R^{2}$ as suggested by Berndt (1991).

In the present case where the estimable model is linear in its parameters iterated GMM and iterated 3SLS yield identical results. However, Wooldridge (2002) recommends using the GMM estimator as it is more general. The GMM estimator produces consistent results even in the presence of serial correlation (and heteroskedasticity if the sample is sufficiently large). By accounting for serial correlation ex ante when constructing the optimal weighting matrix appears more satisfactory than adjusting for serial autocorrelation ex post as is usually done in the literature (Kohli, 1991; Tombazos, 2003). Moreover, ex post adjustment for serial correlation may interfere with instrumenting procedures to account for endogeneity (Tombazos,

2003).

Rather than estimating a complete general equilibrium model to determine output prices we use a number of exogenous variables as proxies for consumer demand, investment, government expenditure and foreign demand, following Kohli (1991). The instruments that are used to take account of the endogeneity of output prices are: lagged population, the lagged total population of the United States, Japan and France, lagged GDP, the lagged real effective exchange rate, the savings ratio, the lagged discount rate, the lagged government's budget deficit as a share of GNP, the lagged capital stock and the squared time trend.

There are two reasons for doing so. First, Berndt and Wood (1981) recommend this as the partial elasticities of complementarity can become quite volatile in the presence of small cost or output shares. Second, Blackorby and Russell (1989) argue that the Allen-Uzawa generalisation to more than two inputs has no meaning as a quantitative measure. 
The quantity elasticity of output supply $i$ with respect to a change in the effective price $j$ is given by:

$$
\varepsilon_{i j}=\frac{\partial \ln y_{i}}{\partial \ln p_{j}}=\frac{\alpha_{i j}}{s_{i}}+s_{j}-\phi_{i j}, \quad \sum_{j=1}^{N} \varepsilon_{i j}=0
$$

where $\phi=1$ if $i=j$. The elasticity of nominal return to factor $k$ with respect to a change in the utilisation of factor $l$ (quantity elasticity of inverse factor demand) is given by:

$$
\varepsilon_{k l}=\frac{\partial \ln w_{k}}{\partial \ln v_{l}}=\frac{\beta_{k l}}{s_{k}}+s_{l}-\phi_{k l}, \quad \sum_{l=1}^{M} \varepsilon_{k l}=0
$$

where $\phi=1$ if $l=k$.

We also calculate the quantity elasticities of output supply, which are given by:

$$
\varepsilon_{i k}=\frac{\partial \ln y_{i}}{\partial \ln v_{k}}=\frac{\gamma_{i k}}{s_{i}}+s_{k}, \quad \sum_{k=1}^{M} \varepsilon_{i k}=1
$$

These correspond to the Rybczynski elasticities, and show the impact of changes in factor endowments on the supply of output from each sector.

The elasticities of inverse factor demand with respect to effective prices are given by:

$$
\varepsilon_{k i}=\frac{\partial \ln w_{k}}{\partial \ln p_{i}}=\frac{\gamma_{k i}}{s_{k}}+s_{i}, \quad \sum_{i=1}^{N} \varepsilon_{k i}=1
$$

These correspond to the Stolper-Samuelson elasticities in trade theory, and show the impact of a change in product market prices on factor rewards.

\section{DATA}

The GNP function will be estimated using annual country-level data for the United Kingdom over the period 1975-1996. However, since we would like to distinguish between the output of skill intensive and un-skill intensive sectors, we begin with a disaggregated dataset for 20 sectors $^{14}$. This is then aggregated for the purposes of the econometric estimation with the measure of skill-intensity used to classify sectors based on the cost share of skilled labour in value-added for 1987. This allows us to derive a series for skilledintensive domestic output $\left(y_{s}\right)$, and unskilled-intensive domestic output $\left(y_{u}\right)$.

The data relating to migrants used in this analysis is taken from the General Household Survey (GHS). This is a continuous national survey conducted annually of people living in

${ }^{14}$ See the Data Appendix for the disaggregation and further details on the dataset. 
private households. It collects data on household, family and individual information. The GHS started in 1971 and is available on a continuous basis until $1996 .{ }^{15}$ The survey asks a number of questions relating to migrant status, the most germane from the point of view of this study being the country of birth of the individual. This allows us to split the sample into native and foreign born components.

For each individual usual work hours are recorded, as is usual gross pay. Taken together with the information on relative stocks, this allows us to split the wage bill into migrant and native components.

The socio-economic group of the individual is also coded, using their current occupation if they are employed, or their usual occupation if they are currently economically inactive. This enables us to also split migrant stocks into skilled and unskilled components, according to the socio-economic group of the worker.

Labour market data are obtained from the New Earnings Survey Panel Data Set (NESPD). Since we want to analyse the increase in wage inequality, workers are classified into skilled and unskilled on the basis of their Standard Occupational Classification (SOC) ${ }^{17}$. The SOC ranks occupations according to the qualifications, training, and experience necessary to perform a particular job and, as such, allows the construction of a more accurate measure of skill than that based on a manual/non-manual distinction that is generally used in the literature (Machin and Van Reenen, 1998; Feenstra and Hanson, 1999).

The original data on producer price indices, TFP and other production data are obtained from the National Institute Sectoral Productivity Database (NISPD).

Thus, GNP is represented as a function of a six-input, two-output technology. The six inputs are: skilled labour $\left(v_{s}\right)$, unskilled labour $\left(v_{u}\right)$, capital $\left(V_{k}\right)$ imports $(m)$, skilled immigrants and unskilled immigrants $\left(n_{s}, n_{u}\right)$. We estimate two different models. We start with a model that assumes that migrant flows are determined exogenously whilst migrant wages are treated as endogenous to the model. In the second model, the number of migrant workers is considered to be endogenously determined and migrant workers are treated in a similar manner to imports- as a negative output ${ }^{18}$.

\footnotetext{
15 The Survey was not conducted in 1997 and 1999. It started reporting on a financial-year basis from 1998, instead of a calendar year.

${ }_{17}^{16}$ Those in the Armed Forces are not included in the sample.

${ }_{18}^{17}$ In a similar manner to Gregory, Zissimos, and Greenhalgh (2001).

18 Descriptive statistics of the dataset employed for the empirical analysis are reported in Table A2.
} 


\section{RESUlts}

Before discussing the estimation results two comments should be made. First, consistency with economic theory requires that the GNP function be convex in prices and concave in factor endowments. Convexity implies that the matrix of second-order derivatives with respect to prices is positive semi-definite, implying that all the principal minors should be positive. The conditions are reversed and analogous for concavity. In the results that follow, the necessary conditions relating to the own price elasticities of output supply and import demand, as well as the own quantity elasticities of inverse factor demand are satisfied naturally (or are insignificant). These are the curvature conditions that are imposed in Harrigan and Balaban (1999), and Harrigan (2000). ${ }^{19}$ A characteristic root test for sign definiteness suggests however that the curvature conditions are violated for most observations.

In principle, it is possible to impose curvature conditions as proposed by Kohli (1991) and Ryan and Wales (2000). However, in the present case imposing curvature conditions rendered convergence impossible ${ }^{20}$ and therefore could not be imposed. Chambers (1988) argues however that the imposition of global curvature properties should be considered secondary to the aim of allowing elasticities to vary over the sample via the use of a flexible functional form specification.

Second, in most cases the quantity elasticities of inverse factor demand are significantly different from zero, which suggests that the factor price insensitivity theorem (FPI) does not hold for the UK. FPI is a key aspect of the Heckscher-Ohlin model and implies that the economy completely adjusts through changes in the output mix rather than through changes in factor prices. In principle, this could be due to, amongst other things, the presence of more factors than tradable goods, which seems plausible at least in the short-run. The failure of FPI is presented as a key result in Harrigan and Balaban (1999) and Harrigan (2000). Consequently, one would also expect changes in relative factor supplies due to immigration to have important consequences for the distribution of earnings.

\section{Trade, Wages and Exogenous Migration}

We initially consider the model in which it is assumed that migration is controlled by government policy and can therefore be considered exogenous. The regression results obtained from estimating the model with exogenous migration are presented in Table 5.

\footnotetext{
19

More precisely, Harrigan and Balaban (1999) and Harrigan (2000) impose the necessary but not sufficient condition that all own price-output elasticities are positive and all own supply-factor price elasticities are negative. More serious may be that they appear to impose the restrictions globally which could damage the flexibility of the translog function (Diewert and Wales, 1987).

20

Imposing curvature conditions renders the regression non-linear. In the context of a system there appears no satisfactory way to determine the appropriate starting values.
} 
Migration, Trade and Wages

Table 5: Regression results for GNP function with exogenous migration

\begin{tabular}{|c|c|c|c|c|c|c|}
\hline \multirow[b]{2}{*}{$\alpha_{1}$} & \multicolumn{3}{|c|}{ ISUR } & \multicolumn{3}{|c|}{ IGMM-AR(1) } \\
\hline & 0.7879 & -55.25 & $* * *$ & 0.7818 & (47.39) & $* * *$ \\
\hline$\alpha_{2}$ & 0.5093 & 80.55 & $* * *$ & 0.5090 & (70.43) & $* * *$ \\
\hline$\beta_{1}$ & 0.1945 & 35.30 & $* * *$ & 0.1830 & (31.90) & $* * *$ \\
\hline$\beta_{2}$ & 0.3401 & 50.09 & $* * *$ & 0.3457 & (47.73) & $* * *$ \\
\hline$\beta_{3}$ & 0.0220 & 8.81 & $* * *$ & 0.0213 & $(9.90)$ & $* * *$ \\
\hline$\beta_{4}$ & 0.0220 & 20.90 & $* * *$ & 0.0216 & (20.13) & $* * *$ \\
\hline$\alpha_{11}$ & 0.4564 & 14.64 & $* * *$ & 0.4735 & $(14.02)$ & $* * *$ \\
\hline$\alpha_{12}$ & -0.3942 & -21.67 & $* * *$ & -0.4001 & $(-19.96)$ & $* * *$ \\
\hline$\alpha_{22}$ & 0.3739 & 17.67 & $* * *$ & 0.3745 & $(16.47)$ & $* * *$ \\
\hline$\beta_{11}$ & 0.1625 & 9.77 & $* * *$ & 0.1339 & $(7.74)$ & $* * *$ \\
\hline$\beta_{12}$ & -0.1319 & -9.11 & $* * *$ & -0.0988 & $(-6.54)$ & $* * *$ \\
\hline$\beta_{13}$ & -0.0064 & -1.21 & & -0.0089 & $(-1.77)$ & $*$ \\
\hline$\beta_{14}$ & -0.0072 & -2.42 & $* *$ & -0.0075 & $(-2.40)$ & $* *$ \\
\hline$\beta_{22}$ & 0.1512 & 9.27 & $* * *$ & 0.1319 & (7.90) & $* * *$ \\
\hline$\beta_{23}$ & -0.0131 & -2.21 & $* *$ & -0.0140 & $(-2.54)$ & $* *$ \\
\hline$\beta_{24}$ & -0.0109 & -4.00 & $* * *$ & -0.0103 & $(-3.73)$ & $* * *$ \\
\hline$\beta_{33}$ & 0.0214 & 4.12 & $* * *$ & 0.0236 & $(4.77)$ & $* * *$ \\
\hline$\beta_{34}$ & -0.0002 & -0.16 & & 0.0017 & (1.06) & \\
\hline$\beta_{44}$ & 0.0104 & 9.53 & $* * *$ & 0.0096 & $(7.60)$ & $* * *$ \\
\hline$\gamma_{11}$ & 0.0416 & 4.45 & $* * *$ & 0.0448 & (4.96) & $* * *$ \\
\hline$\gamma_{12}$ & 0.0500 & 3.71 & $* * *$ & 0.0613 & (4.36) & $* * *$ \\
\hline$\gamma_{13}$ & 0.0066 & 1.00 & & 0.0107 & (1.94) & $*$ \\
\hline$\gamma_{14}$ & -0.0038 & -1.69 & $*$ & -0.0022 & $(-0.90)$ & \\
\hline$\gamma_{21}$ & 0.0188 & 1.80 & $*$ & 0.0129 & $(1.22)$ & \\
\hline$\gamma_{22}$ & -0.0082 & -0.70 & & -0.0047 & $(-0.38)$ & \\
\hline$\gamma_{23}$ & 0.0005 & 0.07 & & -0.0019 & $(-0.33)$ & \\
\hline$\gamma_{24}$ & -0.0037 & -1.43 & & -0.0046 & $(-1.69)$ & $*$ \\
\hline$\delta_{11}$ & 0.0103 & 10.38 & $* * *$ & 0.0112 & (10.04) & $* * *$ \\
\hline$\delta_{21}$ & -0.0091 & -15.12 & $* * *$ & -0.0091 & $(-14.11)$ & $* * *$ \\
\hline$\delta_{12}$ & 0.0004 & 0.70 & & 0.0015 & (2.68) & $* * *$ \\
\hline$\delta_{22}$ & -0.0028 & -4.09 & $* * *$ & -0.0033 & $(-4.74)$ & $* * *$ \\
\hline$\delta_{32}$ & 0.0004 & 1.59 & & 0.0005 & (2.29) & $* *$ \\
\hline$\delta_{42}$ & -0.0005 & -4.09 & $* * *$ & -0.0004 & $(-3.54)$ & $* * *$ \\
\hline $\mathrm{T}(\mathrm{N}+\mathrm{M}-2)$ & & 132 & & & 132 & \\
\hline$\widetilde{R}^{2}$ & & 0.999999 & & & 0.999999 & \\
\hline $\begin{array}{l}\text { Sargan-test } \\
\chi^{2}(63) \\
\end{array}$ & & - & & & 81.3815 & [.059] \\
\hline
\end{tabular}

Robust t-statistics in parentheses, ***, **, *, refer to $1 \%, 5 \%$ and $10 \%$ significance levels. 
Interpretation of these results is aided by the presentation of the estimated elasticities. Tables $6 \mathrm{a}$ and $6 \mathrm{~b}$ represent the full set of price, quantity and time elasticities corresponding to the SUR and GMM results in Table $5^{21}$.

Turning first to the quantity elasticities of inverse factor demand, the own elasticities are negative in line with economic theory, with the own quantity elasticity for capital and for low-skilled non-native workers being statistically significant. A $1 \%$ increase in the supply of unskilled foreign-born workers as a result of controlled immigration policy leads to a $0.3 \%$ reduction in the wage of low-skilled foreign-born workers already present in the labour force.

Looking at the cross elasticities, the estimated impact of immigration on the wage of native workers is found to be negative. However, only the cross elasticity of the supply of lowskilled workers with respect to low skill natives is statistically significant and its economic impact is quantitatively small. A $1 \%$ increase in the supply of unskilled non-native workers reduces the wage of native unskilled by $0.02 \%$, and has no impact on the wage of skilled native workers (although weakly significant in SUR regression). ${ }^{22}$ Moreover, once we note that the number of hours worked by non-natives in the UK economy declined annually by $0.774 \%$, the actual impact of migration on the average hourly earnings of all native workers is positive.

The relationship between migration and imports can be analysed on the basis of either the Rybczinsky elasticities or the Stolper-Samuelson elasticities. Looking at the estimated Rybczsinsky elasticities one observes that skilled migration increases the demand for imports, which suggests that skilled migration and imports are complements. This in line with previous findings in the Canadian and US literature (Gould, 1994; Head and Ries, 1998; Dunlevy and Hutchinson, 1999). Dunlevy and Hutchinson (2001) note that a complementary relationship between migrants and imports is most likely to derive from taste complementarities. By contrast, an increase in the supply of low skilled non-native workers, leads to a reduction in imports, but this effect is statistically insignificant. If anything, this suggests that an increase in the supply of low skilled migrants leads firms to increase their use and substitute away from the use of imports in the production process.

\footnotetext{
${ }^{21}$ The Sargan-test statistic does not reject the null hypothesis of valid overidentifying restrictions $(\mathrm{p}=0.059)$.

The quantity elasticities of inverse factor demand suggest further that the different categories of workers are substitutes to each other, though all are complementary to capital. Perhaps rather surprisingly however, the results suggest that an increase in the supply of capital has a larger positive effect on the wages of unskilled workers than on that of skilled workers. Harrigan (2000) finds ambiguous results with respect to the role of capital accumulation. Tombazos (2003) finds a large positive effect of capital accumulation on wage inequality when using a narrow measure of skill, but only small effects when using a broad measure of skill.
} 
Table 6a: Price, quantity and time elasticities of model with exogenous migration (SUR)

\begin{tabular}{|c|c|c|c|c|c|c|c|c|}
\hline & anys & $d n y_{u}$ & Anm & $\partial n w_{s}$ & $\partial n w_{u}$ & $\partial n w_{n, s}$ & $\partial n w_{n, u}$ & $\partial n w_{k}$ \\
\hline & \multicolumn{3}{|c|}{$\begin{array}{c}\text { Price elasticity } \\
\text { of output supply }\end{array}$} & \multicolumn{5}{|c|}{$\begin{array}{c}\text { Price elasticity of inverse factor demand } \\
\text { (Stolper-Samuelson) }\end{array}$} \\
\hline dnp $p_{s}$ & $\begin{array}{c}0.379 \\
(10.93)\end{array}$ & $\begin{array}{l}0.018 \\
(0.54)\end{array}$ & $\begin{array}{c}1.025 \\
(11.73)\end{array}$ & $\begin{array}{l}1.031 \\
(29.57)\end{array}$ & $\begin{array}{c}0.987 \\
(19.63)\end{array}$ & $\begin{array}{l}1.085 \\
(4.72)\end{array}$ & $\begin{array}{l}0.569 \\
(4.15)\end{array}$ & $\begin{array}{c}0.614 \\
(13.46)\end{array}$ \\
\hline$d n p_{u}$ & $\begin{array}{l}0.011 \\
(0.54)\end{array}$ & $\begin{array}{c}0.255 \\
(7.03) \\
* * *\end{array}$ & $\begin{array}{c}0.423 \\
(11.39) \\
* * *\end{array}$ & $\begin{array}{c}0.580 \\
(12.73) \\
* * *\end{array}$ & $\begin{array}{c}0.461 \\
(12.91) \\
* * *\end{array}$ & $\begin{array}{c}0.505 \\
(1.89) \\
*\end{array}$ & $\begin{array}{l}0.235 \\
(1.26)\end{array}$ & $\begin{array}{c}0.471 \\
(20.80) \\
* * *\end{array}$ \\
\hline \multirow[t]{2}{*}{$d n p_{m}$} & $\begin{array}{c}-0.390 \\
(-11.73) \\
* * *\end{array}$ & $\begin{array}{c}-0.273 \\
(-11.39) \\
* * *\end{array}$ & $\begin{array}{c}-1.447 \\
(-15.98) \\
* * *\end{array}$ & $\begin{array}{c}-0.611 \\
(-15.82) \\
* * *\end{array}$ & $\begin{array}{c}-0.448 \\
(-9.59) \\
* * *\end{array}$ & $\begin{array}{c}-0.590 \\
(-2.87) \\
* * *\end{array}$ & $\begin{array}{l}0.196 \\
(1.42)\end{array}$ & $\begin{array}{c}-0.085 \\
(-2.53) \\
* *\end{array}$ \\
\hline & \multicolumn{3}{|c|}{$\begin{array}{c}\text { Quantity elasticity } \\
\text { of output supply (Rybczinsky) }\end{array}$} & \multicolumn{5}{|c|}{ Quantity elasticity of inverse factor demand } \\
\hline$d n v_{s}$ & $\begin{array}{c}0.254 \\
(29.57) \\
* * *\end{array}$ & $\begin{array}{c}0.242 \\
(12.73) \\
* * *\end{array}$ & $\begin{array}{c}0.396 \\
(15.82) \\
* * *\end{array}$ & $\begin{array}{l}0.002 \\
(0.02)\end{array}$ & $\begin{array}{c}-0.219 \\
(-4.26) \\
* * *\end{array}$ & $\begin{array}{l}-0.047 \\
(-0.22)\end{array}$ & $\begin{array}{c}-0.282 \\
(-1.66) \\
*\end{array}$ & $\begin{array}{c}0.165 \\
(9.66) \\
* * *\end{array}$ \\
\hline$\partial n v_{u}$ & $\begin{array}{c}0.373 \\
(19.63) \\
* * *\end{array}$ & $\begin{array}{c}0.296 \\
(12.91) \\
* * *\end{array}$ & $\begin{array}{c}0.445 \\
(9.59) \\
* * *\end{array}$ & $\begin{array}{c}-0.336 \\
(-4.26) \\
* * *\end{array}$ & $\begin{array}{c}-0.204 \\
(-3.29) \\
* * *\end{array}$ & $\begin{array}{l}-0.197 \\
(-0.98)\end{array}$ & $\begin{array}{c}-0.429 \\
(-3.08) \\
* * *\end{array}$ & $\begin{array}{c}0.323 \\
(8.51) \\
* * *\end{array}$ \\
\hline$d n n_{s}$ & $\begin{array}{c}0.034 \\
(4.72) \\
* * *\end{array}$ & $\begin{array}{c}0.027 \\
(1.89) \\
*\end{array}$ & $\begin{array}{c}0.048 \\
(2.87) \\
* * *\end{array}$ & $\begin{array}{l}-0.006 \\
(-0.22)\end{array}$ & $\begin{array}{l}-0.016 \\
(-0.98)\end{array}$ & $\begin{array}{l}-0.142 \\
(-0.62)\end{array}$ & $\begin{array}{l}0.010 \\
(0.09)\end{array}$ & $\begin{array}{c}0.022 \\
(1.99) \\
* *\end{array}$ \\
\hline$\partial n n_{u}$ & $\begin{array}{c}0.010 \\
(4.15) \\
* * *\end{array}$ & $\begin{array}{l}0.007 \\
(1.26)\end{array}$ & $\begin{array}{l}-0.009 \\
(-1.42)\end{array}$ & $\begin{array}{c}-0.020 \\
(-1.66) \\
*\end{array}$ & $\begin{array}{c}-0.020 \\
(-3.08) \\
* * *\end{array}$ & $\begin{array}{l}0.005 \\
(0.09)\end{array}$ & $\begin{array}{c}-0.280 \\
(-4.22) \\
* * *\end{array}$ & $\begin{array}{c}0.033 \\
(6.48) \\
* * *\end{array}$ \\
\hline \multirow[t]{2}{*}{$d n v_{k}$} & $\begin{array}{c}0.330 \\
(13.46) \\
* * *\end{array}$ & $\begin{array}{c}0.429 \\
(20.80) \\
* * *\end{array}$ & $\begin{array}{c}0.120 \\
(2.53) \\
* *\end{array}$ & $\begin{array}{c}0.361 \\
(9.66) \\
* * *\end{array}$ & $\begin{array}{c}0.459 \\
(8.51) \\
* * *\end{array}$ & $\begin{array}{c}0.380 \\
(1.99) \\
* *\end{array}$ & $\begin{array}{c}0.982 \\
(6.48) \\
* * *\end{array}$ & $\begin{array}{c}-0.543 \\
(-12.24) \\
* * *\end{array}$ \\
\hline & \multicolumn{3}{|c|}{$\begin{array}{c}\text { Time elasticity } \\
\text { of output supply }\end{array}$} & \multicolumn{5}{|c|}{ Time elasticity of inverse factor demand } \\
\hline a & $\begin{array}{c}0.012 \\
(8.16) \\
* * *\end{array}$ & $\begin{array}{c}-0.019 \\
(-18.31) \\
* * *\end{array}$ & $\begin{array}{l}0.004 \\
(1.12)\end{array}$ & $\begin{array}{l}0.002 \\
(0.61)\end{array}$ & $\begin{array}{c}-0.009 \\
(-3.49) \\
* * *\end{array}$ & $\begin{array}{c}0.016 \\
(1.84) \\
*\end{array}$ & $\begin{array}{c}-0.031 \\
(-4.82) \\
* * *\end{array}$ & $\begin{array}{c}0.006 \\
(2.83) \\
* * *\end{array}$ \\
\hline
\end{tabular}

The elasticities correspond to the regression results reported in Table 6. T-statistics in parentheses, ***, **, *, refer to $1 \%, 5 \%$ and $10 \%$ significance levels. 
Table 6b: Price, quantity and time elasticities of model with exogenous migration (GMM)

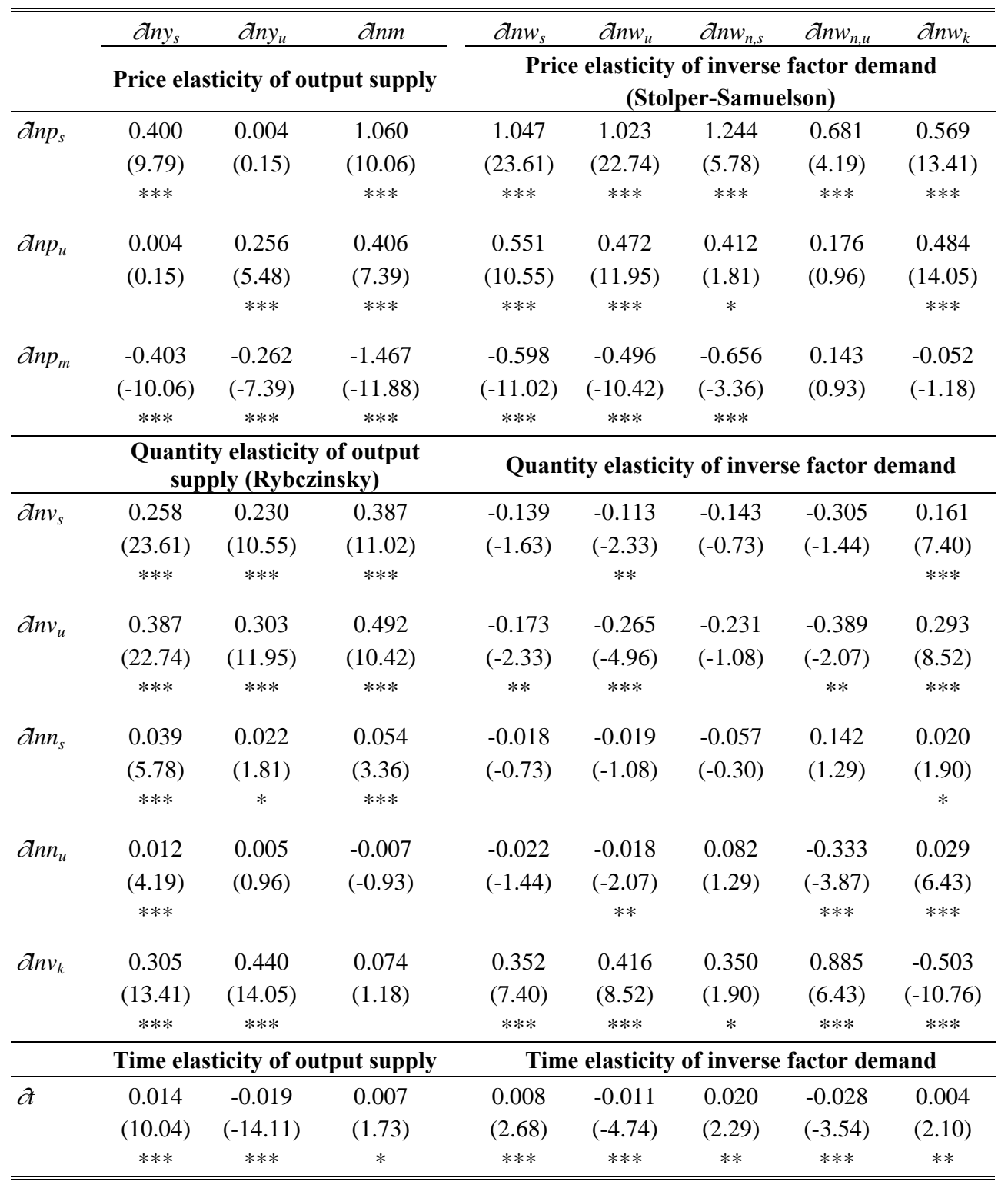

The elasticities correspond to the regression results reported in Table 6. T-statistics in parentheses, ***, **, *, refer to $1 \%, 5 \%$ and $10 \%$ significance levels. 
As one would expect, a similar picture emerges from the Stolper-Samuelson elasticities. A $1 \%$ reduction in the price of imports increases the wages of skilled non-native workers by about $0.6 \%-0.7 \%$, again suggesting that they are complements in production. An increase in the price of imports has a positive, but statistically insignificant, impact on the wage of unskilled non-native workers.

We may also look at the impact of trade liberalisation on the earnings of native workers. Given that imports are treated as intermediate inputs, we would expect that a reduction in their price would allow an increase in the reward of the other factors. This is found to be the case, with the Stolper-Samuelson elasticities suggesting that a reduction in the price of imports has a positive impact on the wages of both types of native workers. The impact of a reduction in import prices is more positive for skilled native workers than for unskilled native workers as usually asserted, although the quantitative difference is relatively small.

The impact of skill-biased technological change (SBTC) on factor rewards is captured by the time elasticity of inverse factor demand. The passage of time appears to have a positive impact on the wages of both native and foreign skilled workers, and a negative effect on unskilled workers. This finding is in line with the literature which attributes the recent rise in wage inequality to SBTC. This development is also evidenced by the time elasticity of output supply which shows an increase in the size of the skilled-labour intensive sector at the expense of unskilled-intensive industries. We also observe that output is becoming more capital intensive and that there is an increase in imports in domestic value-added over time.

\section{Migration and Welfare}

The total impact of an increase in immigration on all domestic factors can be calculated by combining the information relating to returns to individual factors with the information on factor shares. For instance, the impact of a $1 \%$ increase in the rate of skilled migration is given by the factor share weighted average of the quantity elasticities with respect to skilled migration. This quantity is called the 'immigration surplus' by Borjas (1995) and is equal to the increase in national income to non-migrants due to skilled migration.

The economic benefits that we would expect to derive from migration depend on its degree of complementarity with domestic factors of production. Theory predicts that the more different are migrants in terms of their characteristics compared to domestic factors the higher will be the economic benefits. Thus if the UK is relatively skill abundant we would expect larger economic benefits from unskilled migration than from skilled migration. These are what the figures suggest. Skilled migration is associated with an immigration surplus of $0.0095 \%$ in the SUR estimations and $0.0086 \%$ in the GMM estimations. ${ }^{23}$ The impact of $1 \%$ increase in unskilled migration on national income ranges from a surplus of

\footnotetext{
23

For example we calculate the impact of $1 \%$ increase in skilled migration on welfare as follows. From A2 we the vector of factor shares, $\mathbf{s}=\left[\begin{array}{lllll}0.21 & 0.32 & 0.03 & 0.01 & 0.43\end{array}\right]$. From Table 6A we obtain the vector of elasticities of inverse factor demand with respect to skilled migration, $\boldsymbol{\eta}$. We only take into account

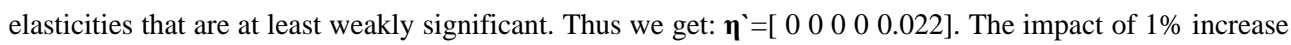
in skilled migration on aggregate welfare is then given by: $\mathbf{s}^{`} \boldsymbol{\eta}=0.0095 \%$.
} 
$0.129 \%$ in the SUR estimates and a surplus of $0.116 \%$ for GMM. These positive impacts of migration on economic welfare derive largely from the positive impact that migration has on the returns to capital.

Perhaps, it would it may be more appropriate to concentrate on the fiscal implications of migration rather than on the contribution of migration on welfare via its impact on the allocation of resources. However, this is beyond the scope of the present paper. Some example of recent studies that do focus on the net fiscal burden of migration are provided by Smith and Edmonston (1997) and Auerbach and Oreopoulos (1999). Such studies typically concentrate on the negative burden imposed on the welfare state by unskilled migration. While migration reduces the dependency ratio at the same time unskilled workers tend to be net beneficiaries of the welfare state.

\section{Trade, Wages and Endogenous Migration}

The results for the model in which it is assumed that migration is driven by economic incentives and is endogenous to the model are represented in Table 7. Again, for ease of interpretation, Tables 8a and $8 \mathrm{~b}$ present the elasticities derived from the SUR and the GMM estimates respectively.

In this variation of the model it is changes in the wages of migrants which impact on the economy, with their effect being measured by the Stolper-Samuelson elasticities. The results show that an increase in the wage of low skilled immigrants leads to a rise in the wage of unskilled native workers as employers substitute native low skilled workers of nonnative unskilled workers. Changes in the wage of skilled non-native workers have no significant effects on the wages of domestic workers.

The relationship between immigration and imports can be analysed by looking at the price elasticities of output supply. A reduction in the price of imports has a negative and significant effect on the demand for skilled migrants and a positive and significant effect on the demand for unskilled migrants. This implies that skilled migrants and imports are complements and unskilled migrants and imports are substitutes. These results are consistent with the findings reported previously for the model with exogenous migration, though the result obtained for the substitutability of unskilled migrants and imports is no longer ambiguous.

${ }^{24}$ See Razin and Sadka (2004) for a critical note on the conclusions reached by such studies. 
Table 7: Regression results for GNP function with endogenous migration

\begin{tabular}{|c|c|c|c|c|c|c|}
\hline \multirow[b]{2}{*}{$\alpha_{1}$} & \multicolumn{3}{|c|}{ ISUR } & \multicolumn{3}{|c|}{ IGMM-AR(1) } \\
\hline & 0.2062 & (25.03) & $* * *$ & 0.0892 & $(5.51)$ & $* * *$ \\
\hline$\alpha_{2}$ & 0.3403 & (33.46) & $* * *$ & -0.1356 & (9.23) & $* * *$ \\
\hline$\alpha_{3}$ & 0.0244 & (7.63) & $* * *$ & 0.0941 & (6.39) & $* * *$ \\
\hline$\alpha_{4}$ & 0.0186 & (16.21) & $* * *$ & 0.7043 & (27.69) & $* * *$ \\
\hline$\beta_{1}$ & 0.7258 & $(46.42)$ & $* * *$ & 0.2220 & (23.96) & $* * *$ \\
\hline$\beta_{2}$ & 0.5617 & (86.28) & $* * *$ & 0.3811 & (37.98) & $* * *$ \\
\hline$\alpha_{11}$ & 0.1625 & $(9.66)$ & $* * *$ & 0.4038 & (15.82) & $* * *$ \\
\hline$\alpha_{12}$ & 0.1319 & (8.21) & $* * *$ & -0.3998 & (18.09) & $* * *$ \\
\hline$\alpha_{13}$ & 0.0064 & (1.18) & & 0.0019 & $(0.33)$ & \\
\hline$\alpha_{14}$ & 0.0072 & (2.85) & $* * *$ & 0.0390 & (5.29) & $* * *$ \\
\hline$\alpha_{22}$ & 0.1512 & $(7.82)$ & $* * *$ & 0.3999 & (18.54) & $* * *$ \\
\hline$\alpha_{23}$ & 0.0131 & (2.54) & $* *$ & 0.0038 & $(0.71)$ & \\
\hline$\alpha_{24}$ & 0.0109 & (5.32) & $* * *$ & -0.0104 & (1.29) & \\
\hline$\alpha_{33}$ & 0.0214 & (3.66) & $* * *$ & -0.0199 & $(5.42)$ & $* * *$ \\
\hline$\alpha_{34}$ & 0.0002 & $(0.16)$ & & 0.0014 & (0.35) & \\
\hline$\alpha_{44}$ & 0.0104 & (10.64) & $* * *$ & 0.0483 & $(4.20)$ & $* * *$ \\
\hline$\beta_{11}$ & 0.4564 & (15.92) & $* * *$ & 0.5692 & $(49.90)$ & $* * *$ \\
\hline$\beta_{12}$ & 0.3942 & (24.13) & $* * *$ & 0.0055 & $(1.27)$ & \\
\hline$\beta_{13}$ & 0.3739 & (21.18) & $* * *$ & -0.0345 & (5.97) & $* * *$ \\
\hline$\gamma_{11}$ & 0.0416 & (5.86) & $* * *$ & -0.0099 & (1.13) & \\
\hline$\gamma_{12}$ & 0.0188 & (2.03) & $* *$ & 0.0430 & (3.89) & $* * *$ \\
\hline$\gamma_{21}$ & 0.0500 & (3.18) & $* * *$ & 0.0127 & (1.42) & \\
\hline$\gamma_{22}$ & 0.0082 & $(0.73)$ & & -0.0155 & (1.48) & \\
\hline$\gamma_{31}$ & 0.0066 & (1.12) & & 0.0047 & (0.99) & \\
\hline$\gamma_{32}$ & 0.0005 & $(0.07)$ & & -0.0202 & (3.98) & $* * *$ \\
\hline$\gamma_{41}$ & 0.0038 & (1.88) & $*$ & -0.0062 & (0.55) & \\
\hline$\gamma_{42}$ & 0.0037 & (1.35) & & 0.0427 & (3.99) & $* * *$ \\
\hline$\delta_{11}$ & 0.0004 & $(0.61)$ & & 0.0114 & $(6.42)$ & $* * *$ \\
\hline$\delta_{21}$ & 0.0028 & (3.49) & $* * *$ & -0.0097 & (11.37) & $* * *$ \\
\hline$\delta_{31}$ & 0.0004 & (1.84) & $*$ & -0.0028 & (8.25) & $* * *$ \\
\hline$\delta_{41}$ & 0.0005 & (4.82) & $* * *$ & 0.0018 & (4.03) & $* * *$ \\
\hline$\delta_{12}$ & 0.0103 & (8.16) & $* * *$ & -0.0008 & (1.14) & \\
\hline$\delta_{22}$ & 0.0091 & (18.31) & $* * *$ & -0.0063 & (8.16) & $* * *$ \\
\hline $\mathrm{T}(\mathrm{N}+\mathrm{M}-2)$ & & 132 & & & 132 & \\
\hline$\tilde{R}^{2}$ & & 0.999999 & & & 0.999999 & \\
\hline $\begin{array}{l}\text { Sargan-test } \\
\chi^{2}(63)\end{array}$ & & - & & & 71.7436 & [.211] \\
\hline
\end{tabular}

Robust t-statistics in parentheses, ***, **, *, refer to $1 \%, 5 \%$ and $10 \%$ significance levels. 


\section{Table 8a:}

Price, quantity and time elasticities of model with endogenous migration (SUR)

\begin{tabular}{|c|c|c|c|c|c|c|c|c|}
\hline & $d n y_{s}$ & $d n y_{u}$ & $d n n_{s}$ & $\partial n n_{u}$ & dnm & $\partial n w_{s}$ & $\partial n w_{u}$ & $d n w_{k}$ \\
\hline & \multicolumn{5}{|c|}{ Price elasticity of output supply } & \multicolumn{3}{|c|}{$\begin{array}{l}\text { Price elasticity of inverse factor } \\
\text { demand (Stolper-Samuelson) }\end{array}$} \\
\hline \multirow[t]{3}{*}{$d n p_{s}$} & 0.324 & -0.055 & 0.630 & -2.402 & 1.008 & 0.817 & 1.083 & 0.735 \\
\hline & $(13.88)$ & $(-1.49)$ & $(2.31)$ & $(-3.57)$ & $(14.91)$ & $(16.51)$ & (20.70) & $(28.43)$ \\
\hline & $* * *$ & & $* *$ & $* * *$ & $* * *$ & $* * *$ & $* * *$ & $* * *$ \\
\hline \multirow[t]{3}{*}{$d n p_{u}$} & -0.030 & 0.339 & 0.428 & 1.766 & 0.390 & 0.488 & 0.374 & 0.474 \\
\hline & $(-1.49)$ & $(10.60)$ & $(1.77)$ & $(2.25)$ & $(6.63)$ & $(12.61)$ & $(6.76)$ & $(22.87)$ \\
\hline & & $* * *$ & $*$ & $* *$ & $* * *$ & $* * *$ & $* * *$ & $* * *$ \\
\hline \multirow[t]{3}{*}{$\partial n w_{n, s}$} & -0.020 & -0.024 & -0.325 & -0.264 & -0.058 & -0.003 & -0.119 & 0.004 \\
\hline & $(-2.31)$ & $(-1.77)$ & $(-1.86)$ & $(-1.04)$ & $(-3.34)$ & $(-0.11)$ & $(-4.37)$ & $(0.73)$ \\
\hline & $* *$ & * & $*$ & & $* * *$ & & $* * *$ & \\
\hline \multirow[t]{3}{*}{$\partial n w_{n, u}$} & 0.036 & -0.049 & -0.128 & -4.282 & 0.225 & -0.061 & 0.240 & -0.101 \\
\hline & (3.57) & $(-2.25)$ & $(-1.04)$ & $(-4.80)$ & (3.81) & $(-0.83)$ & (3.11) & $(-8.66)$ \\
\hline & $* * *$ & $* *$ & & $* * *$ & $* * *$ & & $* * *$ & $* * *$ \\
\hline \multirow[t]{4}{*}{$d n p_{m}$} & -0.350 & -0.248 & -0.644 & 5.143 & -1.603 & -0.280 & -0.616 & -0.151 \\
\hline & $(-14.91)$ & $(-6.63)$ & $(-3.34)$ & (3.81) & $(-14.83)$ & $(-2.36)$ & $(-5.24)$ & $(-6.98)$ \\
\hline & $* * *$ & $* * *$ & $* * *$ & $* * *$ & *** & $* *$ & *** & $* * *$ \\
\hline & \multicolumn{5}{|c|}{$\begin{array}{c}\text { Quantity elasticity of output supply } \\
\text { (Rybczinsky) }\end{array}$} & \multicolumn{3}{|c|}{$\begin{array}{c}\text { Quantity elasticity } \\
\text { of inverse factor demand }\end{array}$} \\
\hline \multirow[t]{3}{*}{$d n v_{s}$} & 0.205 & 0.225 & 0.025 & 1.002 & 0.203 & -0.369 & -0.484 & 0.314 \\
\hline & (16.51) & (12.61) & $(0.11)$ & $(0.83)$ & (2.36) & $(-4.69)$ & $(-7.86)$ & (8.67) \\
\hline & $* * *$ & $* * *$ & & & $* *$ & $* * *$ & $* * *$ & $* * *$ \\
\hline \multirow[t]{3}{*}{$d n v_{u}$} & 0.252 & 0.160 & 0.886 & -3.678 & 0.413 & -0.449 & -0.305 & 0.279 \\
\hline & (20.70) & (6.76) & (4.37) & $(-3.11)$ & (5.24) & $(-7.86)$ & $(-4.73)$ & (14.63) \\
\hline & $* * *$ & $* * *$ & $* * *$ & $* * *$ & $* * *$ & $* * *$ & $* * *$ & $* * *$ \\
\hline \multirow[t]{4}{*}{$d n v_{k}$} & 0.389 & 0.461 & -0.066 & 3.522 & 0.230 & 0.663 & 0.634 & -0.748 \\
\hline & (28.43) & (22.87) & $(-0.73)$ & (8.66) & (6.98) & (8.67) & (14.63) & $(-18.67)$ \\
\hline & $* * *$ & $* * *$ & & $* * *$ & $* * *$ & $* * *$ & $* * *$ & $* * *$ \\
\hline & \multicolumn{5}{|c|}{ Time elasticity of output supply } & \multicolumn{3}{|c|}{$\begin{array}{c}\text { Time elasticity } \\
\text { of inverse factor demand }\end{array}$} \\
\hline \multirow[t]{3}{*}{ 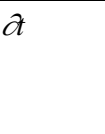 } & 0.014 & -0.022 & 0.098 & -0.180 & 0.006 & -0.005 & -0.032 & 0.017 \\
\hline & $(4.73)$ & $(-11.50)$ & $(8.48)$ & $(-4.07)$ & $(0.55)$ & $(-1.73)$ & $(-7.51)$ & $(6.87)$ \\
\hline & $* * *$ & $* * *$ & $* * *$ & $* * *$ & & $*$ & $* * *$ & $* * *$ \\
\hline
\end{tabular}

The elasticities correspond to the regression results reported in Table 7. T-statistics in parentheses, ***, **, *, refer to $1 \%, 5 \%$ and $10 \%$ significance levels. 
Table 8b: Price, quantity and time elasticities of model with endogenous migration (GMM)

\begin{tabular}{|c|c|c|c|c|c|c|c|c|}
\hline & dny $_{s}$ & $d n y_{u}$ & $\partial n n_{s}$ & $\partial n n_{u}$ & dnm & $\partial n w_{s}$ & $\partial n w_{u}$ & $\partial n w_{k}$ \\
\hline & \multicolumn{5}{|c|}{ Price elasticity of output supply } & \multicolumn{3}{|c|}{$\begin{array}{c}\text { Price elasticity of inverse factor } \\
\text { demand (Stolper-Samuelson) }\end{array}$} \\
\hline \multirow[t]{3}{*}{$d n p_{s}$} & 0.313 & 0.006 & 0.781 & -1.672 & 0.955 & 0.772 & 0.963 & 0.757 \\
\hline & $(10.15)$ & $(0.14)$ & (3.59) & $(-3.54)$ & $(16.02)$ & $(17.83)$ & $(27.59)$ & (26.36) \\
\hline & $* * *$ & & $* * *$ & $* * *$ & $* * *$ & $* * *$ & $* * *$ & $* * *$ \\
\hline \multirow[t]{3}{*}{$d n p_{u}$} & 0.004 & 0.308 & 0.330 & 1.244 & 0.464 & 0.545 & 0.441 & 0.494 \\
\hline & $(0.14)$ & $(7.04)$ & (1.59) & $(2.42)$ & $(10.61)$ & (12.35) & (13.48) & $(19.86)$ \\
\hline & & $* * *$ & & $* *$ & $* * *$ & $* * *$ & $* * *$ & $* * *$ \\
\hline \multirow[t]{3}{*}{$d n w_{n, s}$} & -0.024 & -0.017 & -0.325 & -0.139 & -0.061 & 0.008 & -0.093 & 0.006 \\
\hline & $(-3.59)$ & $(-1.59)$ & $(-2.33)$ & $(-0.55)$ & $(-3.02)$ & (0.35) & $(-5.81)$ & $(0.78)$ \\
\hline & $* * *$ & & $* *$ & & $* * *$ & & & \\
\hline \multirow[t]{3}{*}{$d n w_{n, u}$} & 0.030 & -0.038 & -0.080 & -3.876 & 0.206 & -0.064 & 0.125 & -0.091 \\
\hline & (3.54) & $(-2.42)$ & $(-0.55)$ & $(-5.19)$ & (4.04) & $(-1.18)$ & (3.76) & $(-7.47)$ \\
\hline & $* * *$ & $* *$ & $* * *$ & $* * *$ & $* * *$ & & $* * *$ & $* * *$ \\
\hline \multirow[t]{4}{*}{$d n p_{m}$} & -0.363 & -0.299 & -0.747 & 4.403 & -1.605 & -0.302 & -0.476 & -0.207 \\
\hline & $(-16.02)$ & $(-10.61)$ & $(-3.02)$ & (4.04) & $(-17.06)$ & $(-3.55)$ & $(-8.99)$ & $(-8.00)$ \\
\hline & $* * *$ & $* * *$ & $* * *$ & $* * *$ & $* * *$ & $* * *$ & $* * *$ & $* * *$ \\
\hline & \multicolumn{5}{|c|}{$\begin{array}{l}\text { Quantity elasticity of output supply } \\
\text { (Rybczinsky) }\end{array}$} & \multicolumn{3}{|c|}{$\begin{array}{c}\text { Price elasticity of inverse factor } \\
\text { demand (Stolper-Samuelson) }\end{array}$} \\
\hline \multirow[t]{3}{*}{$\partial n v_{s}$} & 0.190 & 0.227 & -0.064 & 0.881 & 0.195 & -0.358 & -0.229 & 0.307 \\
\hline & (17.83) & (12.35) & $(-0.35)$ & (1.18) & (3.55) & $(-4.47)$ & $(-4.86)$ & (12.18) \\
\hline & $* * *$ & $* * *$ & & & $* * *$ & $* * *$ & $* * *$ & $* * *$ \\
\hline \multirow[t]{3}{*}{$\partial n v_{u}$} & 0.364 & 0.283 & 1.136 & -2.648 & 0.473 & -0.352 & -0.388 & 0.406 \\
\hline & (27.59) & (13.48) & (5.81) & $(-3.76)$ & (8.99) & $(-4.86)$ & $(-8.27)$ & (15.85) \\
\hline & $* * *$ & $* * *$ & $* * *$ & $* * *$ & $* * *$ & $* * *$ & $* * *$ & $* * *$ \\
\hline \multirow[t]{4}{*}{$d n v_{k}$} & 0.406 & 0.450 & -0.112 & 2.727 & 0.292 & 0.669 & 0.578 & -0.753 \\
\hline & (26.36) & (19.86) & $(-0.78)$ & $(7.47)$ & $(8.00)$ & (12.18) & (15.85) & $(-17.02)$ \\
\hline & $* * *$ & $* * *$ & & $* * *$ & $* * *$ & $* * *$ & $* * *$ & $* * *$ \\
\hline & \multicolumn{5}{|c|}{ Time elasticity of output supply } & \multicolumn{3}{|c|}{$\begin{array}{c}\text { Time elasticity } \\
\text { of inverse factor demand }\end{array}$} \\
\hline \multirow[t]{3}{*}{$\partial$} & 0.014 & -0.020 & 0.104 & -0.124 & 0.003 & -0.003 & -0.020 & 0.016 \\
\hline & $(6.40)$ & $(-11.59)$ & $(8.10)$ & $(-4.22)$ & $(0.45)$ & $(-0.91)$ & $(-8.29)$ & $(6.35)$ \\
\hline & $* * *$ & $* * *$ & $* * *$ & $* * *$ & & & $* * *$ & $* * *$ \\
\hline
\end{tabular}

The elasticities correspond to the regression results reported in Table 8 . T-statistics in parentheses, ***, **, *, refer to $1 \%, 5 \%$ and $10 \%$ significance levels. 
A similar story is told by examination of the elasticity of imports with respect to changes in the wages of skilled and unskilled migrants. An increase in the wage of skilled migrants causes a fall in imports, whilst an increase in the wage of unskilled migrants causes a decline.

\section{CONCLUSIONS}

In this paper we simultaneously analysed the impact of trade and migration on the UK economy using data for the period 1975-1996. More in particularly, we evaluate in a single framework to what extent migration affects the distribution of income and how migration and UK trade are interrelated.

With regard to the impact of immigration on domestic factor returns, we arrive at very similar conclusions whether we treat migration as exogenous (and determined by administrative controls) or endogenous (and responding to factor rewards). In the former case, a relaxation of controls, which allows an increase in the number of unskilled migrants, reduces the wages of unskilled workers. While the quantitative impact on foreign born unskilled workers is sizeable it is very small for native unskilled workers. By contrast, relaxing controls on the entry of skilled workers appears to have no discernible impact on their domestic counterparts, with the wages of both skilled native and foreign-born workers remaining unaffected.

When the number of migrants is treated as endogenous to the model, we measure the effect of migration by the impact of changes in the migrant wage. As before, this analysis indicates that unskilled migrants and unskilled domestic workers are substitutes, though no similar effect is observed for skilled workers. Again the effect is quantitatively small.

Concerning the impact of migration on imports we find that that an increase in unskilled migrants reduces imports whilst an increase in skilled overseas workers sucks in more imports. This suggests that unskilled migrant workers and imports are substitutes in production, whilst skilled migrant workers and imports are complements. This presumably reflects the low skilled labour that is embodied in imports.

When we look at the overall impact of migration on the welfare of domestic factors we find that the contribution of unskilled immigration to national income is greater than that of skilled immigration. This suggests that unskilled migrants play a more complementary role to domestic factors than do skilled migrants. However, in economic terms the impact of migration on aggregate welfare is quite small, which is perhaps not surprising given the relatively small redistributive effects.

In short, we conclude from the results that the current political furore over migration cannot be justified by looking for labour market consequences of migration, since these impacts prove to be modest. 


\section{REFERENCES}

Auerbach, A. and P. Oreopoulos (1999), "Analyzing the Fiscal Impact of U.S. Immigration”, American Economic Review, Papers and Proceedings 89(May), 176180.

Bell, B. D. (1997), "The Performance of Immigrants in the United Kingdom: Evidence from the GHS”, Economic Journal, Vol. 107(127), pp. 333-344.

Berndt, E.R. and D.O. Wood (1975), “Technology, Prices, and the Derived Demand for Energy”, Review of Economics and Statistics, Vol. 57, Iss. 3, pp. 259-268.

Berndt, E.R. (1991), The Practice of Econometrics: Classics and Contemporary, Reading, MA: Addison-Wesley.

Berndt, E.R. and D.O. Wood (1981), "Engineering and Econometric Interpretations of Energy-Capital Complementarity: Reply and Further Results", American Economic Review, Vol. 71, Iss. 5, pp. 1105-1110.

Blackorby, C. and R.R. Russell (1989), "Will the Real Elasticity of Substitution Please Stand Up? (A Comparison of the Allen/Uzawa and Morishima Elasticities)", American Economic Review, Vol. 79, No. 4, pp. 882-888.

Borjas, G.J. (1995), “The Economic Benefits from Immigration”, Journal of Economic Perspectives, Vol. 9, No. 2, pp. 3-22.

Borjas, G.J, R.B. Freeman, and L.R. Katz (1992). 'On the Labor Market Effects of Immigration and Trade”. in George Borjas and Richard Freeman, eds. Immigration and the Workforce. Chicago: University of Chicago Press/NBER, pp. 213-244.

Burgess, D.F. (1974), "Production Theory and the Derived Demand for Imports", Journal of International Economics, Vol. 4, No.2, pp. 103-117.

Chambers, R.G. (1988), Applied Production Analysis, Cambridge (UK): Cambridge University Press.

Clarke, J. and J. Salt (2003), "Work permits and foreign labour in the UK: a statistical review”, Labour Market Trends, 111(11):563-74, London: HMSO.

Diewert, W.E. and T.J. Wales, (1987), "Flexible Functional Forms and Global Curvature Conditions”, Econometrica, Vol. 55, Iss.1, pp. 43-68.

Dunlevy, J.A. and W.K. Hutchinson (1999), "The Impact of Immigration on American Import Trade in the Late Nineteenth and Early Twentieth Centuries", Journal of Economic History, Vol. 59, pp. 1043-1062. 
Dunlevy, J.A. and W.K. Hutchinson (2001), "The Pro-Trade Effect of Immigration on American Exports During the Late Nineteenth and Early Twentieth Centuries”, IZA Discussion Paper, no. 375.

Feenstra, R.C. and G.H. Hanson (1999), “The Impact of Outsourcing and High-Technology Capital on Wages: Estimates for the United States, 1979-1990”, Quarterly Journal of Economics, Vol. 114, Iss. 3, pp. 907-941.

Gaston, N and N. Nelson (2002) 'The Wage and Employment Effects of Immigration: Trade and Labour Economics Perspectives', in D. Greenaway, R. Upward, and K. Wakelin (Eds.) Trade, Investment, Migration and Labour Market Adjustment. 2002, Basingstoke: Palgrave Macmillan, pp. 201-235.

Glover, S., C. Gott, A. Loizillon, J. Portes, R. Price, S. Spencer, S. Srinivasan and Wills (2001) Migration: an economic and social analysis, London: Home Office, RDS Occasional Paper No. 67.

Gould, D.M. (1994), "Immigrant Links to the Home Country: Empirical Implications for U.S. Bilateral Trade Flows”, Review of Economics and Statistics, Vol. 76, pp. 189194.

Gregory, M., B. Zissimos, and C. Greenhalgh (2001), "Jobs for the skilled: how technology, trade, and domestic demand changed the structure of UK employment, 1979-1990”, Oxford Economic Papers, Vol. 53, No. 1, pp. 20-41.

Harrigan, J. (2000), "International Trade and American Wages in General Equilibrium, 1967-1995”, in R.C. Feenstra (ed.), The Impact of International Trade on Wages, University of Chicago Press: Chicago.

Harrigan, J. and R. Balaban (1999), "U.S. Wages in General Equilibrium: The Effect of Prices, Technology, and Factor Supplies, 1963-1991”, NBER Working Paper, No. 6981.

Head, K. and J. Ries (1998), "Immigration and Trade Creation: Econometric Evidence from Canada”, Canadian Journal of Economics, Vol. 31, pp. 47-62.

Huddle, D. (1993), “The costs of immigration”, unpublished paper, Rice University.

Kohli, U. (1991), Technology, Duality and Foreign Trade: The GNP Function Approach to Modelling Imports and Exports, Hemel Hempstead: Harvester Wheatsheaf.

Kohli, U. (1999), "Trade and Migration: A Production Theory Approach", in Ricardo Faini, Jaime de Melo, and Klaus F. Zimmermann (eds.), Migration: The Controversies and the Evidence, Cambridge: Cambridge University Press.

Kohli, U. (2002), "Migration and Foreign Trade: Further Results", Journal of Population Economics, Vol. 15, pp. 381-387. 
Machin, S. and J. van Reenen (1998), "Technology and Changes in Skill Structure: Evidence form Seven OECD Countries", Quarterly Journal of Economics, Vol. 113, pp. 1215-1244.

Mundell, R.(1957), “International Trade and Factor Mobility”, American Economic Review, Vol.47, Iss. 3, pp. 321-335.

O’Mahony, M. (1999), Britain’s productivity performance 1950-1996: An international perspective, NIESR.

Razin, A and E. Sadka (2004), "Welfare Migration: Is the Net Fiscal Burden a Good Measure of its Economic Impact on the Welfare of the Native-Born Population?”, CESifo Economic Studies, Vol. 50, 4/2004.

Rendall, M.S. and D.J. Ball (2004), “Immigration, emigration and the ageing of the overseas-born population in the United Kingdom”, Population Trends, 116: 18-27.

Ryan, D.L. and T.J. Wales (2000), "Imposing Local Concavity in the Translog and Generalized Leontief Cost Functions”, Economics Letters, Vol. 67, pp. 253-260.

Smith, J.P. and B. Edmonston (1997), The New Americans: Economic, Demographic and Fiscal Effects of Immigration, Washington D.C.: National Academy Press.

Slaughter, M (1999), “Globalization and wages: a tale of two perspectives”, World Economy, 22, 609-30.

Tombazos, C.G. (2003), “A Production Theory Approach to the Imports and Wage Inequality Nexus”, Economic Inquiry, Vol. 41, No. 1, pp. 42-61.

Turrini, A. (2002), 'International trade and labour market performance: major findings and open questions.' Policy issues in International Trade and Commodities Study Series No. 20, United Nations

Wooldridge, J.M. (2002), Econometric Analysis of Cross Section and Panel Data, Cambridge MA: MIT.

Zellner, A. (1962), “An Efficient Method of Estimating Seemingly Unrelated Regressions and Tests for Aggregation Bias”, Journal of the American Statistical Association, Vol. 57, No. 298, pp. 348-368. 


\section{DATA APPENDIX}

The data relating to migrants used in this analysis is taken from the General Household Survey. Individuals are classified as skilled or unskilled according to their socio-economic grouping. Skilled workers comprise: professional workers, senior managers and skilled manual workers; The unskilled comprise intermediate and junior non-manual, semi and unskilled manual. Members of the Armed Forces are excluded.

Labour market data are obtained from the New Earnings Survey Panel Data Set (NESPD). The NESPD is conducted annually by the Office for National Statistics and covers approximately one percent of the working population. The survey is directed to employers who complete it on the basis of payroll records for the employee for a specific week in April. The NESPD tends to under represent employees whose income falls below the national insurance threshold. The present study uses information on male workers, aged between 18-65, that work full-time, are not self-employed, and whose earnings are not affected by absence.

Data on producer price indices, TFP and other production data are obtained from the National Institute Sectoral Productivity Database (NISPD). This is publicly available from the NIESR. For more information on the sources and the construction of these variables the reader is referred to O’Mahony (1999). This database contains annual data for five major industrial economies on, amongst others, real output, employment, labour productivity, capital stocks, and TFP for about 25 sectors for the period 1950-1999.

Disaggregated producer price indices for the UK are only available for the 1990s for the UK and only for manufacturing industries. However, Indices of Production are available at the sectoral level for both services and manufacturing. Such indices should reflect the growth in output by sector in real terms. This index has been compiled on a more or less consistent basis since the 1940s. The construction of these indices is based on turnover data deflated using weighted combinations of producer price indices and export price indices. Without having data on price indices one could retrieve the 'producer price indices' by combining data on value added at current prices with the index of production, that is, to convert nominal value-added into an index $(1995=100)$ and subsequently divide the index of value added (current prices) by the index of production (constant prices). Obviously constructing producer price indices for services is subject to many problems. In particular, output indices might not just reflect real growth of output in services due to the difficulty to disentangle cost-price effects from volume effects. Data on output indices and nominal value added are obtained from the ONS. 
Table A1: Industry classification based on skilled labour cost share in value-added

\begin{tabular}{ll}
\hline \hline \multicolumn{1}{c}{ Unskilled $\left(y_{u}\right)$} & \multicolumn{1}{c}{ Skilled $\left(y_{s}\right)$} \\
\hline Agriculture and Forestry & Paper and printing \\
Mining and extraction & Chemicals \\
Food, drink and tobacco & Total machinery \& equipment \\
Textiles, clothing and leather & Electricity, gas and water \\
Wood products & Retail \\
Rubber \& Plastics & Financial \& business services \\
Non-metallic mineral products & Communications \\
Basic metals \& fabricated metal products & Personal services \\
Furniture and miscellaneous & \\
Construction & \\
Hotels and catering & \\
Transport & \\
\hline \hline
\end{tabular}

Table A2: Descriptive statistics, 1975-1996

\begin{tabular}{lcccc}
\hline \hline & Average & Percentage change* & & Percentage change* \\
\multicolumn{2}{c}{ Output/Import shares } & & Output/Import prices and TFP \\
$y_{s}$ & 0.89 & 0.51 & $p_{s}$ & 3.28 \\
$y_{u}$ & 0.41 & -0.41 & $p_{u}$ & 3.49 \\
$m$ & -0.29 & -0.10 & $p_{m}$ & 1.40 \\
& & & $T F P_{S}$ & 1.33 \\
& & & $T F P_{u}$ & 2.44 \\
Cost shares & & & & \\
$s_{s}$ & 0.21 & 0.38 & $v_{s}$ & 1.81 \\
$s_{u}$ & 0.32 & -0.91 & $v_{u}$ & -1.59 \\
$s_{k}$ & 0.43 & 0.54 & $v_{k}$ & 0.74 \\
$s_{n, s}$ & 0.03 & 0.05 & $n_{s}$ & 0.30 \\
$s_{n, u}$ & 0.01 & -0.02 & $n_{u}$ & -0.77 \\
\hline \hline
\end{tabular}

The cost shares for migrants are calculated as positive cost share rather than negative output shares. The measure of skill-intensity used to classify sectors is based on the cost share of skilled labour in value-added the year 1987.

* Average annual percentage changes 


\section{LIST OF WORKING PAPERS RELEASED BY CEPII ${ }^{25}$}

No

Title

2005-05 Institutional Determinants of Foreign Investment

2005-04 L’économie indienne: changements structurels et perspectives à long terme

2005-03 Programme de travail du CEPII pour 2005

2005-02 Market Access in Global and Regional Trade

2005-01 Real Equilibrium Exchange Rate in China

2004-22 A Consistent, ad-valorem Equivalent Measure of Applied Protection Across the World: The MacMapHS6 Database

2004-21 IMF in Theory: Sovereign Debts, Judicialisation and Multilateralism

2004-20 The Impact of Multilateral Liberalisation on European Regions: a CGE Assessment

2004-19 La compétitivité de l'agriculture et des industries agroalimentaires dans le Mercosur et l'Union européenne dans une perspective de libéralisation commerciale

2004-18 Multilateral Agricultural Trade Liberalization: The Contrasting Fortunes of Developinc Countries in the Doha Round

2004-17 UK in or UK out? A Common Cycle Analysis between the UK and the Euro Zone
Authors

A. Bénassy-Quéré, M. Coupet \& T. Mayer

S. Chauvin \& F. Lemoine

T. Mayer \& S. Zignago

V. Coudert \&

C. Couharde

A. Bouët, Y. Decreux, L. Fontagné, S. Jean \& D. Laborde J. Sgard

S. Jean \& D. Laborde

N. Mulder, A. Vialou, B. David, M. Rodriguez \& M. Castilho

A. Bouët, J.C. Bureau, Y. Decreux \& S. Jean

J. Garnier

\footnotetext{
${ }^{25}$ Working papers are circulated free of charge as far as stocks are available; thank you to send your request to CEPII, Sylvie Hurion, 9, rue Georges-Pitard, 75015 Paris, or by fax : (33) 0153685504 or by e-mail Hurion@cepii.fr. Also available on: Ilwww.cepii.fr. Working papers with * are out of print. They can nevertheless be consulted and downloaded from this website.

${ }^{25}$ Les documents de travail sont diffusés gratuitement sur demande dans la mesure des stocks disponibles. Merci d'adresser votre demande au CEPII, Sylvie Hurion, 9, rue Georges-Pitard, 75015 Paris, ou par fax : (33) 0153685504 ou par e-mail Hurion@cepii.fr. Egalement disponibles sur : Ilwww.cepii.fr.

Les documents de travail comportant* sont épuisés. Ils sont toutefois consultable sur le web CEPII.
} 
2004-16 Regionalism and the Regionalisation of International Trade

2004-15 The Stock-Flow Approach to the Real Exchange Rate of CEE Transition Economies

2004-14 Vieillissement démographique, épargne et retraite : une analyse à l'aide d'un modèle d'équilibre général à agents hétérogènes

2004-13 Burden Sharing and Exchange-Rate Misalignments within the Group of Twenty

2004-12 Regulation and Wage Premia

2004-11 The Efficiency of Fiscal Policies: a Survey of the Literature

2004-10 La réforme du marché du travail en Allemagne : les enseignements d'une maquette

2004-09 Typologie et équivalence des systèmes de retraites

2004-08 South - South Trade: Geography Matters

2004-07 Current Accounts Dynamics in New EU Members: Sustainability and Policy Issues

2004-06 Incertitude radicale et choix du modèle

2004-05 Does Exchange Rate Regime Explain Differences in Economic Results for Asian Countries?

2004-04 Trade in the Triad: How Easy is the Access to Large Markets?

2004-03 Programme de travail du CEPII pour 2004

2004-02 Technology Differences, Institutions and Economic Growth: a Conditional Conditional Convergence

2004-01 Croissance et régimes d'investissement

2003-22 A New Look at the Feldstein-Horioka Puzzle using a Integrated Panel

2003-21 Trade Linkages and Exchange Rates in Asia :The Role of China
G. Gaulier, S. Jean \&

D. Ünal-Kesenci

B. Egert,

A. Lahrècche-Révil \&

K. Lommatzsch

C. Bac \& J. Chateau

A. Bénassy-Quéré,

P. Duran-Vigneron,

A. Lahrèche-Révil \&

V. Mignon

S. Jean \& G. Nicoletti

S. Capet

S. Capet

P. Villa

S. Coulibaly \&

L. Fontagné

P. Zanghieri

P. Villa

V. Coudert \&

M. Dubert

L. Fontagné, T. Mayer

\& S. Zignago

H. Boulhol

P. Villa

A. Banerjee

P. Zanghieri

A. Bénassy-Quéré \& A. Lahrèche-Révil 
2003-20 Economic Implications of Trade Liberalization Under the Doha Round

J. Francois, H. van Meijl \&

F. van Tongeren

2003-19 Methodological Tools for SIA - Report of the CEPII Worshop held on 7-8 November 2002 in Brussels

2003-18 Order Flows, Delta Hedging and Exchange Rate Dynamics

B. Rzepkowski

2003-17 Tax Competition and Foreign Direct Investment

A. Bénassy-Quéré,

L. Fontagné \&

A. Lahrèche-Révil

F. Lemoine \&

2003-16 Commerce et transfert de technologies: les cas comparés de la Turquie, de l'Inde et de la Chine

D. Ünal-Kesenci

2003-15 The Empirics of Agglomeration and Trade

K. Head \& T. Mayer

F. Legros French and German Point Systems

2003-13 How Different is Eastern Europe? Structure and Determinants of Location Choices by French Firms in Eastern and Western Europe

2003-12 Market Access Liberalisation in the Doha Round: Scenarios and Assessment

A.C. Disdier \& T. Mayer

L. Fontagné, J.L. Guérin \& S. Jean

2003-11 On the Adequacy of Monetary Arrangements in SubSaharian Africa

A. Bénassy-Quéré \& M. Coupet

2003-10 The Impact of EU Enlargement on Member States: a CGE Approach

H. Bchir, L. Fontagné \& P. Zanghieri

2003-09 India in the World Economy: Traditional Specialisations and Technology Niches

S. Chauvin \&

F. Lemoine

2003-08 Imitation Amongst Exchange-Rate Forecasters: Evidence from Survey Data

M. Beine,

A. Bénassy-Quéré \&

H. Colas

2003-07 Le Currency Board à travers l'expérience de S. Chauvin \& P. Villa l'Argentine

2003-06 Trade and Convergence: Revisiting Ben-Davil

G. Gaulier

B. Egert \&

2003-05 Estimating the Fundamental Equilibrium Exchange Rate of Central and Eastern European Countries the EMU Enlargement Perspective 


\title{
CEPII \\ DOCUMENTS DE TRAVAIL / WORKING PAPERS
}

\author{
Si vous souhaitez recevoir des Documents de travail, \\ merci de remplir le coupon-réponse ci-joint et de le retourner à : \\ Should you wish to receive copies of the CEPII's Working papers, \\ just fill the reply card and return it to: \\ Sylvie HURION - Publications \\ CEPII - 9, rue Georges-Pitard - 75740 Paris - Fax : (33) 1.53.68.55.04
}

M./Mme / Mr./Mrs

Nom-Prénom / Name-First name

Titre / Title

Service / Department.

Organisme / Organisation

Adresse / Address.

Ville \& CP / City \& post code

Pays / Country Tél.

Désire recevoir les Document de travail du CEPII $n^{\circ}$ :

Wish to receive the CEPII's Working Papers No:

Souhaite être placé sur la liste de diffusion permanente (pour les bibliothèques) Wish to be placed on the standing mailing list (for Libraries). 